\title{
IoT Technology Applications-Based Smart Cities: Research Analysis
}

\author{
Mariana-Daniela González-Zamar ${ }^{1,2, *(\mathbb{0})}$, Emilio Abad-Segura ${ }^{3, *} \mathbb{C}$, Esteban Vázquez-Cano 4 (D) \\ and Eloy López-Meneses ${ }^{5,6}$ (D) \\ 1 Department of Education, University of Almeria, 04120 Almeria, Spain \\ 2 Higher Technical School of Architecture of Seville, Avenida de la Reina Mercedes, 2, 41012 Seville, Spain \\ Department of Economics and Business, University of Almeria, 04120 Almeria, Spain \\ 4 Department of Didactics and School Organization, National University of Distance Education, \\ 28040 Madrid, Spain; evazquez@edu.uned.es \\ 5 Department of Education and Social Psychology, Pablo de Olavide University, 41013 Seville, Spain; \\ elopmen@upo.es \\ 6 Research Institute in Social Sciences and Education, Vice-Rectory for Research and Postgraduate, \\ University of Atacama, Copiapó 1530000, Chile \\ * Correspondence: mgz857@ual.es (M.-D.G.-Z.); eas297@ual.es (E.A.-S.)
}

Received: 23 July 2020; Accepted: 1 August 2020; Published: 2 August 2020

\begin{abstract}
The development of technologies enables the application of the Internet of Things (IoT) in urban environments, creating smart cities. Hence, the optimal management of data generated in the interconnection of electronic sensors in real time improves the quality of life. The objective of this study is to analyze global research on smart cities based on IoT technology applications. For this, bibliometric techniques were applied to 1232 documents on this topic, corresponding to the period 2011-2019, to obtain findings on scientific activity and the main thematic areas. Scientific production has increased annually, so that the last triennium has accumulated $83.23 \%$ of the publications. The most outstanding thematic areas were Computer Science and Engineering. Seven lines have been identified in the development of research on smart cities based on IoT applications. In addition, the study has detected seven new future research directions. The growing trend at the global level of scientific production shows the interest in developing aspects of smart cities based on IoT applications. This study contributes to the academic, scientific, and institutional discussion to improve decision making based on the available information.
\end{abstract}

Keywords: smart city; internet of the things; application; technology; scientific production

\section{Introduction}

In recent years, digitization of society and transformation of business sector have allowed the development of cities based on Internet of Things (IoT) technology, the hyperconnection of electronic devices, and the interpretation of data that these generate [1,2]. Therefore, the purpose of smart cities is to achieve a more sustainable and livable environment that improves the quality of life of citizens based on IoT technological innovation [3].

In a broad sense, IoT consists of digital interconnection of everyday objects, through sensors that capture real-world data that are sent to platforms for processing, and these through service platforms become information and actions $[4,5]$. The analysis of data allows generating a better understanding of data and making optimal decisions. In this sense, the application of IoT in urban environments allows the development of smart cities, so that one concept is inextricably linked to the other. The application of this technology will drive production models such as Industry 4.0 [6], the development of new 
consumption and production models from the innovation of the Circular Economy [7], the intelligent management of public and private resources $[8,9]$, the appearance of smart citizens by evaluating their opinions in real time [10], and intelligent mobility from public transport and traffic control. In this order, mobile connectivity is fundamental, and it is fundamentally based on 5G [11,12] technology.

Consequently, the smart city is defined as an urban space that performs more efficient management of its community services through digital technology. Such is the case of intelligent traffic management with the aim of reducing air, light, and noise pollution; improving the safety and health of citizens through Big Data; or developing a smart economy through sensors that help optimize available resources [13-15]. Hence, the development of smart and connected cities will depend on effective measures to guarantee the security of communications and data that will be transferred from IoT devices $[16,17]$.

This approach justifies the research interest. Therefore, the motivation of this study is to document the evolution of the global knowledge base on smart cities based on IoT technology applications. Furthermore, the reviewed literature has allowed to focus on this topic, so that the research questions seek to find answers to the following. (1) What is the global structure of knowledge on smart cities based on IoT technology applications? (2) Who are the authors, research institutions, and the most productive countries? (3) What are the thematic axes that this research topic develops? (4) What are the future directions of research?

The main objective of this study is to analyze global research of the smart cities based on IoT technology applications, during the period 2011-2019. To obtain answers to the research questions, a sample of 1232 articles from scientific journals selected from Scopus database was analyzed. This work uses the bibliometric method to synthesize the global knowledge base on smart cities based on IoT technology applications. The results showed the contributions in this research field, so that it has allowed identifying the main driving agents (authors, research institutions, and countries), and current and future research directions.

This study presents a set of limitations, some defined by the research itself. For example, others unrelated to this refer to the difficulty of distinguishing whether the growth in the volume of articles published in the examination period can be related, among other causes, to the exponential development of digital technologies, with regulatory regulation, or with the demands of stakeholders.

Among the research lines developed at the international level, they mainly refer to the analysis of a smart city' holistic vision; to studying IoT applications; to analyzing network security solutions; to identifying all macroscopic approaches to wireless telecommunication systems; to the implications of Internet in smart cities development; to cloud computing and the availability of data centers; and, finally, to the automation of processes.

Globally, research on smart cities based on IoT technology applications continues to progress, so this study has identified new directions in the research, which should contribute to the development of different aspects.

To achieve the stated objective, this study is organized as follows. Section 2 justifies the relevance of the research topic, delimiting the unit of analysis and conducting a review of the background, theoretical principles, and a conceptual framework of smart cities based on IoT technology applications. Section 3 details the methodology applied in this study. Section 4 shows and discusses the main results obtained. To close, the last section is dedicated to presenting the main conclusions of this research.

\section{Scope of Research}

Section 2 provides the theoretical principles and provides the definition of the key concepts that will be used in the analysis of the study on smart cities based on IoT technology applications, to avoid different interpretations of these. The purpose of this section is to serve as a guide for research and to offer theoretical and conceptual frameworks for interpreting the results and discussions of the next section. 


\subsection{Backgrounds}

The evolution of smart cities based on IoT technology applications has been shaped by a series of chronological events. In this way, the Internet emerged connecting people through machines or devices. This was the origin of the IoT, with the purpose of moving the network to the objects, connecting them, and exchanging information [18].

In 1999, N. Gershenfeld, from the Massachusetts Institute of Technology (MIT), established the rights of things, in the sense of having identity, accessing other objects, and detecting their surroundings $[19,20]$. Thereby, in 2005, the International Telecommunication Union (ITU), from the United Nations, presented its report on the IoT, indicating that the next step would be to integrate things into a ubiquitous communication network - that is, anywhere, anytime, by anyone, and with anything. The technologies that made this network possible were radio frequency identification tags, wireless sensors, embedded intelligence, and nanotechnology. Likewise, the IoT user contemplates three levels of experiences: (1) tangible, which involves the introduction into the body of a device that allows data transmission; (2) the connection and sharing of information, and (3) visualization and reflection, which enables the acquisition of a broader knowledge of the environment and the objects we use [21-23].

With the development of this technology, IoT has been applied in cities. Thereby, Smart City is the most ambitious representation, whose purpose is to bring together intelligent systems that manage information around the factors that influence the positive evolution of the city, such as the economic, political, social, environmental, public and private mobility, and quality of life $[12,15,24]$.

\subsection{Framework}

This research study is sustained by a set of theoretical principles, which together with the basic concepts define the framework for global research of the smart cities based on IoT technology applications. Moreover, a set of concepts related to the subject of study have been defined, which introduce part of the concepts that will stand out in the results and discussions due to their importance and connection.

In a first bibliographic search with the purpose of delimiting the research problem and avoiding approaches that are not connected with the study, a set of articles is identified that includes the essential concepts, provides evidence and an initial synthesis on the subject, and allows defining the objective of the research. Table 1 shows the main articles selected after reviewing the literature on the research topic, establishing a framework between the theoretical basis and the terminology of smart cities based on IoT technology applications at an international level. For this reason, the documents in Table 1 focus on the theoretical and conceptual structure of the research topic. This analysis has allowed determining the problem, the purpose, and the objective of the research, as well as obtaining the key terms to apply the methodology specified in Section 3.

Table 1. Key documents to define the research.

\begin{tabular}{cccc}
\hline Year & Article Title [Reference] & Author(s) & Journal \\
\hline 2019 & $\begin{array}{c}\text { A Digital Model for Smart City using Internet of } \\
\text { Things (IoT) [25] }\end{array}$ & Alam, K. & Global Sci-Tech \\
\hline 2019 & $\begin{array}{c}\text { Structuring Reference Architectures for the } \\
\text { Industrial Internet of Things [26] }\end{array}$ & $\begin{array}{c}\text { Bader, S.R.; } \\
\text { Maleshkova, M.; } \\
\text { Lohmann, S. }\end{array}$ & Future Internet \\
\hline 2019 & Blockchain Powered Smart Cities [27] & $\begin{array}{c}\text { Dhondse, A.; } \\
\text { Singh, S. }\end{array}$ & $\begin{array}{c}\text { Communications on } \\
\text { Applied Electronics }\end{array}$ \\
\hline 2019 & $\begin{array}{c}\text { Communication Protocols of an Industrial Internet } \\
\text { of Things Environment: A Comparative Study [28] }\end{array}$ & Jaloudi, S. & Future Internet \\
\hline
\end{tabular}


Table 1. Cont.

\begin{tabular}{|c|c|c|c|}
\hline Year & Article Title [Reference] & Author(s) & Journal \\
\hline 2019 & $\begin{array}{c}\text { IoT Based Smart City with Vehicular Safety } \\
\text { Monitoring [29] }\end{array}$ & $\begin{array}{l}\text { Mohapatra, H.; } \\
\text { Behura, A. }\end{array}$ & $\begin{array}{l}\text { Internet of Things and } \\
\text { Cloud Computing }\end{array}$ \\
\hline 2019 & $\begin{array}{l}\text { Blockchain-Supported Smart City Platform for } \\
\text { Social Value Co-Creation and Exchange [30] }\end{array}$ & $\begin{array}{l}\text { Scekic, O.; Nastic, } \\
\text { S.; Dustdar, S. }\end{array}$ & IEEE Internet Computing \\
\hline 2018 & $\begin{array}{c}\text { Redefining the Smart City: Culture, Metabolism, } \\
\text { and Governance [31] }\end{array}$ & $\begin{array}{l}\text { Allam, Z.; } \\
\text { Newman, P. }\end{array}$ & Smart Cities \\
\hline 2018 & $\begin{array}{l}\text { Smart cities and urban data platforms: Designing } \\
\text { interfaces for smart governance [32] }\end{array}$ & Barns, S. & City, Culture and Society \\
\hline 2018 & $\begin{array}{l}\text { IoT-based reconfigurable smart city } \\
\text { architecture [33] }\end{array}$ & $\begin{array}{l}\text { Geetha } \\
\text { Pratyusha, M.; } \\
\text { Misra, Y.; Anil } \\
\text { Kumar, M. }\end{array}$ & $\begin{array}{l}\text { International Journal of } \\
\text { Engineering \& } \\
\text { Technology }\end{array}$ \\
\hline 2018 & $\begin{array}{l}\text { Artificial Intelligence-Based Semantic Internet of } \\
\text { Things in a User-Centric Smart City [34] }\end{array}$ & $\begin{array}{l}\text { Guo, K.; Lu, Y.; } \\
\text { Gao, H.; Cao, R. }\end{array}$ & Sensors \\
\hline 2018 & $\begin{array}{c}\text { Development of Information Evaluation System for } \\
\text { Smart City Planning Using Geoinformatics } \\
\text { Techniques [35] }\end{array}$ & $\begin{array}{l}\text { Persai, P.; Katiyar, } \\
\text { S.K. }\end{array}$ & $\begin{array}{l}\text { Journal of the Indian } \\
\text { Society of Remote } \\
\text { Sensing }\end{array}$ \\
\hline 2018 & $\begin{array}{c}\text { A Comprehensive Study on Smart City using } \\
\text { Blockchain Technology [36] }\end{array}$ & Raja, A. & $\begin{array}{l}\text { International Journal of } \\
\text { Computer Sciences and } \\
\text { Engineering }\end{array}$ \\
\hline 2018 & $\begin{array}{c}\text { Smart City Development with Urban Transfer } \\
\text { Learning [37] }\end{array}$ & $\begin{array}{l}\text { Wang, L.; Guo, B.; } \\
\text { Yang, Q. }\end{array}$ & Computer \\
\hline 2016 & $\begin{array}{l}\text { Cloud computing security: protecting cloud-based } \\
\text { smart city applications [38] }\end{array}$ & Giannakoulias, A. & Journal of Smart Cities \\
\hline 2015 & $\begin{array}{c}\text { An Information Framework for Creating a Smart } \\
\text { City Through Internet of Things [39] }\end{array}$ & $\begin{array}{l}\text { Poslad, S.; Ma, A.; } \\
\text { Wang, Z.; Mei, H. }\end{array}$ & Sensors \\
\hline 2014 & $\begin{array}{c}\text { Using a Smart City IoT to Incentivise and Target } \\
\text { Shifts in Mobility Behaviour-Is It a Piece of } \\
\text { Pie? [40] }\end{array}$ & $\begin{array}{l}\text { Jin, J.; Gubbi, J.; } \\
\text { Marusic, S.; } \\
\text { Palaniswami, M. }\end{array}$ & $\begin{array}{l}\text { IEEE Internet of Things } \\
\text { Journal }\end{array}$ \\
\hline
\end{tabular}

The literature review has established the framework of this research field related to, among other aspects, Information and Communication Technologies (ICT), efficient urban planning, educational technologies, transparency between local governments and citizens, technologies applied to the health sector, open data, sustainable urban mobility, efficient waste management, automation and control in smart buildings, air pollution management, crime prevention and criminal activity through smart video surveillance, or sustainable public lighting.

The basis of research on smart cities based on IoT technology applications is confirmed by a set of theoretical principles. Hence, digital transformation consists of the reinvention or evolution of an entity using digital technology to improve performance [41,42]. The Internet and digital technologies, influenced by the speed of growth, transform business models and business sectors, establishing a new digital economy with a social, cultural, and economic impact. Thus, to conduct digital transformation optimally, whether in a company or in a city, the digitization of its strategic processes is key. This contributes to a better understanding of the business, optimizing decision-making, improving efficiency in each area, and increasing competitiveness [43,44].

Likewise, it is necessary to establish the key concepts or variables in the context of this research. First, the Internet refers to the decentralized set of interconnected communication networks, which ensures that the heterogeneous physical networks that comprise it constitute a single logical network with global reach. Its origin comes from ARPAnet (Advanced Research Projects Agency Network), in 1969, when the first connection between Stanford and UCLA computers arose [45-47]. 
Along these lines, the concept of Internet of Things (IoT), a term first coined in 1999 as a key element of digital transformation and the digital economy, refers to digital interconnection of everyday objects with the Internet, thus becoming smart objects. In other words, it consists of connecting the Internet with objects, mainly through sensors that send and receive data continuously, and then after their interpretation, proceed to carry out actions $[48,49]$. This term signals a radical change in the quality of life of people in society, since it allows new opportunities for access to data, educational services, security, healthcare, communications, and transportation. The unquestionable relevance of IoT is in the substantial changes that they suppose in society, notably in sectors such as Industry 4.0, smart cities, e-health, finance, tourism, education, business, entrepreneurship, or cybersecurity [50-52].

In relation to the subject of study, the concept of the city refers to the settlement of population with attributions and political, administrative, economic, and religious functions. This concept is reflected in the specific location of buildings and in its urban configuration. In other words, a city is an urban space with a high population density, with commerce, industry, and services predominating [53,54].

In this sense, a smart city is considered an evolution of city, since it uses technology, innovation, and other resources to promote sustainable development and improve the quality of life of its citizens $[55,56]$. It includes the concepts of energy efficiency and sustainability, contributing to the balance between the environment and the consumption of natural resources. Likewise, it refers to the city with investments in human and social capital, and in communication infrastructures, which promote sustainable development and quality of life $[57,58]$. It is also considered as a prototype for urban planning and development, an answer to environmental problems, as well as a solution to energy problems. Among its advantages, the following stand out: (1) a decrease in spending dedicated to the provision and management of public services; (2) offers a platform for innovation; (3) increases the efficiency and quality of services, appropriately managing resources; (4) facilitates the identification of the needs of city; (5) offers real-time information; (6) increases the transparency of the Local Administrations; and (7) promotes social development [59-61].

\subsection{Related Concepts}

To build an underlying conceptual structure on this theme, other concepts have been identified that form the knowledge base on smart cities based on IoT technology applications. Hence, terms such as Sensor, Application, Big Data, Blockchain, and Machine Learning are defined below in the context of this research.

A key concept to understand the implications of smart cities based on IoT technology applications is the sensor. This is a device to detect external actions or stimuli and respond accordingly $[62,63]$. In other words, they allow the information from the physical environment to be captured, and then the physical or chemical quantities to be measured and transformed into electrical signals so that they can be understood by a microcontroller [64].

In this order, an application consists of a computer program used as a tool that enables a user to perform tasks, and they belong to the application software. In general, a computer application is geared toward automating complicated tasks $[65,66]$. As a result of technological evolution, consolidated global start-ups and suppliers constantly innovate in new applications to respond to the needs that arise. Thus, the implementation of solutions for more devices with IoT will have an impact on development and security of smart cities $[67,68]$.

Likewise, the concept of Big Data refers to the management and analysis of enormous volumes of data that cannot be processed in a conventional way, by overcoming the limits and capabilities of the software tools commonly used for data capture, management, and processing [69,70]. The purpose of Big Data, in the same way as conventional analytical systems, is to convert the data into suitable information for decision-making. This term encompasses technological infrastructures and services created to provide solutions to the processing of huge structured, unstructured, or semi-structured datasets $[71,72]$. 
In this technology, the term Blockchain refers to a shared database for the registration of transactions. Each block has a specific place in the chain, since each contains information from the hash of the previous block. The complete chain is saved in each node of the network that makes up the Blockchain [73,74]. As new records are created, they are first verified and validated by network nodes; then, they are added to a new block that binds to the chain. Blockchain technology allows storing information that can never be lost, modified, or deleted. Each node of the network uses certificates and digital signatures to verify the information and validate the transactions and data stored on Blockchain, which allows ensuring the authenticity of said information $[75,76]$. Therefore, any type of information that needs to be preserved intact and that must remain available can be stored on the Blockchain in a secure, decentralized, and cheaper way than through intermediaries. Moreover, if this information is kept encrypted, its confidentiality can be guaranteed. Therefore, its use can be applied, among others, to the economy, health, and IoT [77-79].

In this context, the Machine Learning concept refers to the scientific discipline in the field of Artificial Intelligence that creates systems that automatically learn $[80,81]$. The machine that really learns is an algorithm that reviews data and can predict future behavior. It automatically implies that these systems improve autonomously over time, without human intervention. In practice, it is used, for example, to predict urban traffic, make medical pre-diagnoses based on patient symptoms, or detect intrusions in a data communications network $[82,83]$.

\section{Materials and Methods}

Section 3 shows the methodology applied in this study, and the data collection procedure, based on research questions, that will make up the article sample. Subsequently, they will be processed, analyzed, and interpreted.

\subsection{Bibliometric Method}

Bibliometrics applies mathematical and statistical methods to scientific literature, to analyze the activity of a certain scientific field. This methodology was started by E. Garfield in the middle of the 20th century, and since then, it has become generalized in the analysis of scientific research and has contributed to reviewing knowledge in multiple disciplines [84,85]. In this way, bibliometrics has evolved from reflection on scientific development and from the availability of numerous databases accessible to the researcher.

It has also become an indispensable tool for managers and specialists in management or in organizations that develop research or innovation programs. Quantitative studies, based on bibliometrics, enrich the understanding and description of the dynamics of activity and scientific production [86-88].

In recent years, bibliometric methodology has encouraged the revision of different schools of scientific knowledge. It has been used by numerous scientists, including management, finance, economics, and education [89-91]. Bibliometric indicators are the instruments used to measure the results of scientific activity in any of its manifestations [92].

\subsection{Search Criteria and Data Collection}

The aim of this study is to determinate the general dynamics of the smart cities based on IoT technology applications research at a global level. Hence, a quantitative analysis is performed using the bibliometric method. According to the main literature reviewed on this topic, which is presented in Table 1, the terms chosen in the search string have been "internet of things" and "smart city".

Mainly, the preference of the Scopus database for the analysis of the document sample is due to the fact that when performing the initial search in the Web of Science (WoS) and Scopus databases, it showed a significant difference in the volume of articles during the period analyzed (2011-2019). That is, from WoS, 264 articles were extracted, while from Scopus, 1232 articles were extracted. 
Scopus has a number of advantages over WoS, such as: (1) it is considered the largest deposit of peer-reviewed literature; (2) it minimizes the risk of losing documents during the search; (3) it is easily accessible; (4) it offers tools for data visualization and analysis; (5) it allows the sample to be downloaded in different formats; and (6) it presents a wide variety of data $[93,94]$.

Hence, the procedure followed to select the sample on research in IoT and smart cities is adjusted to the flowchart of Figure 1, in relation to the Preferred Reporting Elements for Systematic Reviews and Meta-Analyses (PRISMA) [95].

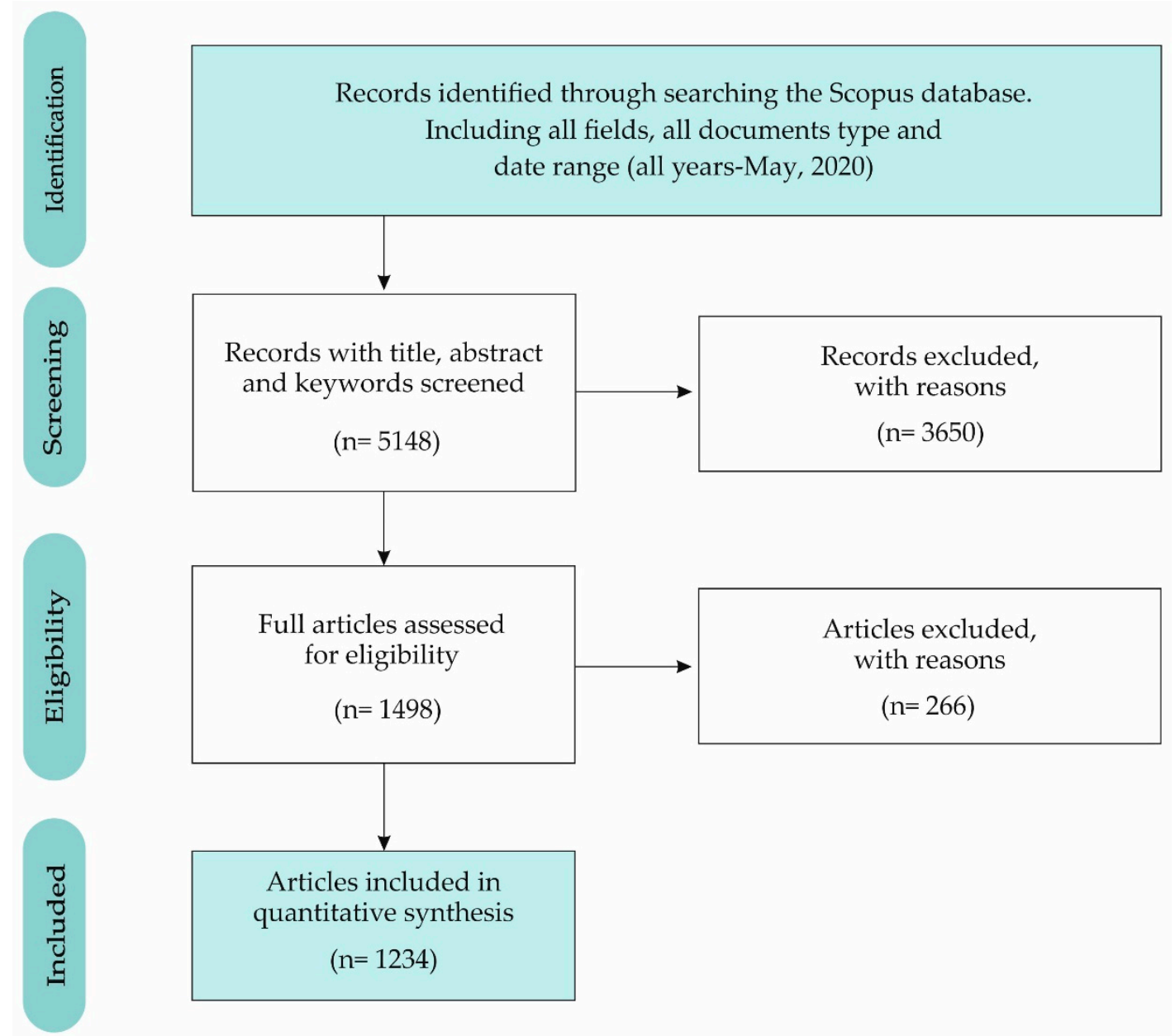

Figure 1. PRISMA flowchart (Preferred Reporting Items for Systematic Reviews and Meta-Analyses (PRISMA)).

In phase 1 (identification), 22,621 records were identified from the Scopus database, considering all the fields for each of the key search terms (internet of things, smart city), all types of documents, and all years in the data range (All years to Present: May 2020).

Next, in phase 2 (screening) the option of "article title, abstract and keywords" was chosen in the field of each term; consequently 17,513 were excluded, so that 5148 records remained.

In phase 3 (eligibility), only the "articles" were selected as the type of document, to guarantee the quality derived from the peer review process. Therefore, 3650 documents were excluded, and 1498 records were obtained.

The time horizon analysis was between 2011 and 2019, and both years were included-that is, from the publication of the first article on this topic (2011) to the last full year (2019). For these reasons, in the last phase (included), 266 documents were excluded, so the final sample included 1232 articles. 
The search selected records from the subfields of title, abstract, and keywords, in the period that contains the last 9 years (2011-2019). This procedure has been successfully applied in numerous studies that have used the bibliometric method [96,97].

\subsection{Data Processing}

In this research study, the indicators of scientific production analyzed have been the distribution by years of the published articles and the productivity of the authors, research institutions, and countries. The quality indicators used and referred to the impact of the different agents of this research topic have been (1) the count of the number of citations; (2) the h-index, which allows to detect which are the most outstanding authors in the discipline, based on the number of citations that have received their scientific articles [98]; and (3) the 2018 CiteScore indicator, which is obtained from the calculation of the number of citations in a year received by academic articles published in a journal in the 3 immediately preceding years, divided by the total number of articles published during those same 3 years [99]; (4) the 2018 SCImago Journal Rank (SJR), which measures the quality of the scientific journals included in Scopus database [100]; and (5) the 2018 Source Normalized Impact per Paper (SNIP), which counts the number of citations received by a journal for three years divided by the potential citation from the journal's scientific field [101].

Likewise, the indicators of the collaboration structure, which measure the links between the authors, research institutions, and countries, have been analyzed using the processing tools and network maps due to their reliability and suitability in bibliometric analysis, using the co-authorship method. Co-authorship of an article is an official declaration of the participation of two or more authors, organizations, or countries. Thereby, co-authorship analysis is widely used to understand and evaluate patterns of scientific collaboration. For this, in co-authoring networks, nodes represent authors, organizations, or countries that are connected when they share the authorship of an article [102,103].

The analysis of the keywords has allowed the detection of the main current or future research topics, based on the analysis of co-occurrences, since scientific texts can be reduced to the set of joint appearances between the words it comprises [104,105]. The co-occurrence of two concepts is very high if they frequently appear together in one set of documents and rarely do so separately in the rest. With the analysis of co-occurrences, the proximity relationship of two or more terms in a text unit is established. Furthermore, the graphic representation of the co-occurrence networks allows them to be viewed [106-108]. For the analysis of these relationship indicators, the software VOSviewer (version 1.6.10, Leiden University, Leiden, The Netherlands) has been applied, which provides data on collaborations and the evaluation of the contents, in order to measure the activities of the research networks [109,110].

The findings gained are valuable for a group of actors involved in scientific research on the evolution and innovation of smart cities based on IoT technology applications and who demand an examination of past and future information, such as engineers, analysts investment, academics, researchers, research institutes, universities, government agencies, materials, and services providers, among others.

\section{Results and Discussion}

Section 4, first, presents and discusses the main results of the evolution of scientific production in a global context on smart cities based on IoT technology applications. Then, the distribution of articles by subject area and journal is analyzed. Later, the results obtained from the analysis of the main keywords associated with this topic are discussed, which allowed identifying the main current lines. Next, the main keywords and subject areas associated with the most prolific authors, research institutions, and countries are presented. Lastly, future research directions are presented. 


\subsection{Scientific Production}

Section 4.1 displays the evolution of scientific production on smart cities based on IoT technology applications. The interest of the scientific and academic community has increased significantly since 2011, when the first 2 articles on this topic were published, up to 95 in the last year analyzed (2019).

The repercussion of this theme is better understood when it is observed that $95.78 \%$ of the total has been published in the last five years (1180 articles), in the last triennium, $83.20 \%$ (1025), and in the last year, $40.02 \%$ (493).

Figure 2 shows the evolution of the total of the 1232 articles identified in the search carried out in the Scopus database. The polynomial trend line of order 2 indicates that the number of articles in this research topic increases more rapidly over time, in the last 9 years. This trend line, shaped like a parabola, displays a practically perfect goodness of fit to the data, with a coefficient of determination close to $1\left(R^{2}=0.983\right)$. The second-order polynomial model turned out to be the most appropriate for obtaining the growth curve.

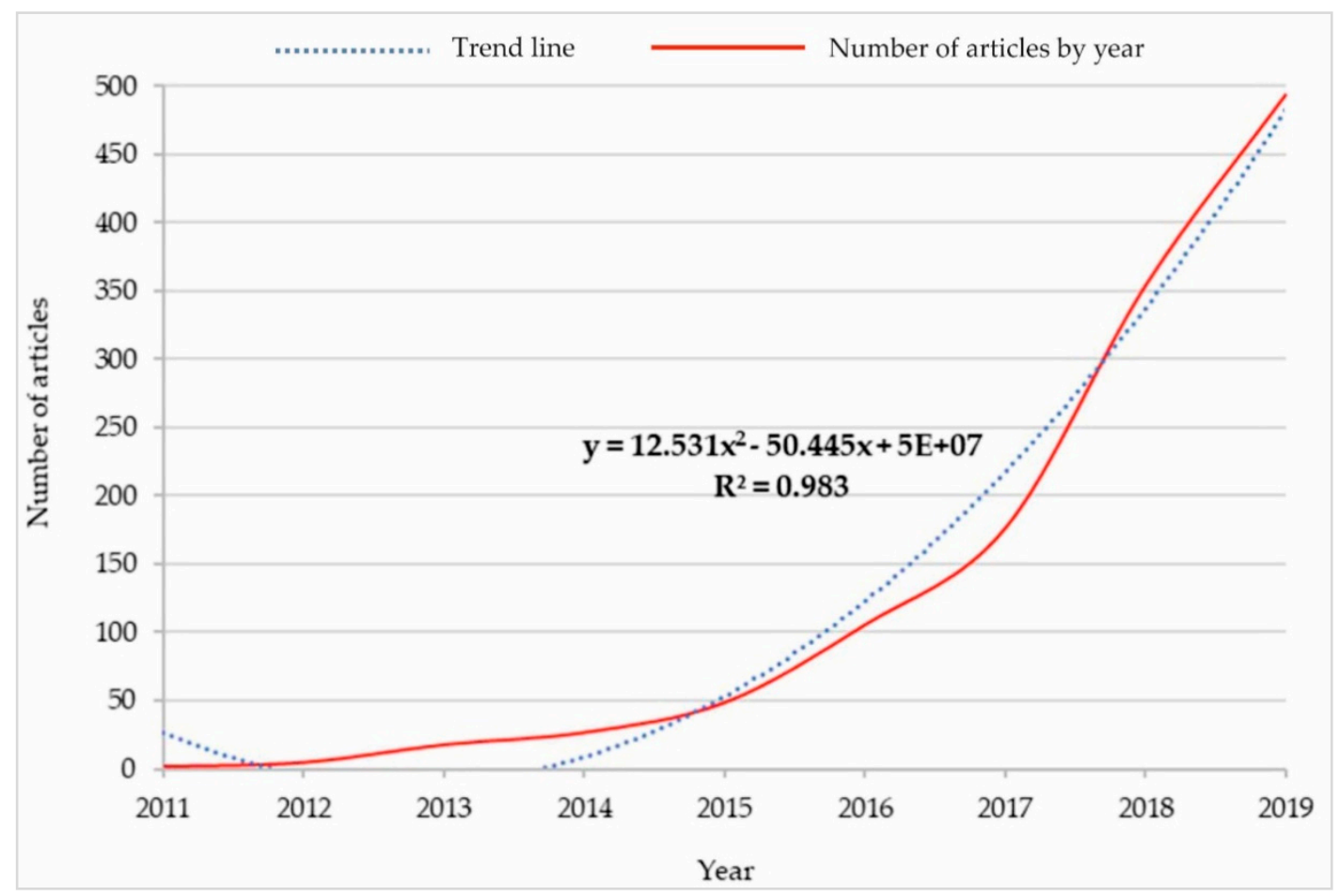

Figure 2. Evolution of scientific production (2011-2019).

The evolution of scientific production in this area of knowledge is part of the result of the fourth Industrial Revolution on a global scale, which is related to computing, transmission, and analysis of data, sensors and low-cost communication devices, and hyperconnectivity enabled by the digital ecosystem [111,112].

Furthermore, IoT transformation by connecting society and the business world has led to the dynamism of industries and their processes, as well as the appearance of new business models, effective health systems, new products and services, and, in particular, smarter cities that are also sustainable $[113,114]$. This transformation has also influenced research, where a growth in scientific activity is observed at the international level in recent years. In other words, scientific production reflects innovation and the changes that disruptive technologies and connectivity entail. Likewise, cooperation between the main actors that make up the core of scientific activity on smart cities based on IoT technology applications is a key factor in this growth $[115,116]$.

In this research topic, $98.30 \%$ of the articles are written in English (1211). This circumstance is related to the fact that the publication in this language broadens its audience, as it happens widely in 
the searches made in the Scopus database [117]. In addition, the articles have been published in other languages with less representation: Chinese (12, 0.97\%), Persian (3, 0.24\%), German (2, 0.16\%), Polish, Portuguese, and Russian (1, $0.08 \%$ each one of them).

\subsection{Subject Areas and Journals}

This section shows and discusses the main subject areas into which scientific production is classified and the analysis of the main journals on smart cities based on IoT technology applications, during the 2011-2019 period.

Hence, the 1232 articles are classified into 23 subject areas, according to the Scopus database. In this sense, an article could be classified in more than one subject area, or in a single area. There is a correlation between the subject areas and the journals, with the publisher being the journal who ends up cataloguing each article in a thematic area. Figure 3 presents the classification of these 23 main subject areas where articles are classified in worldwide research on smart cities based on IoT technology applications.

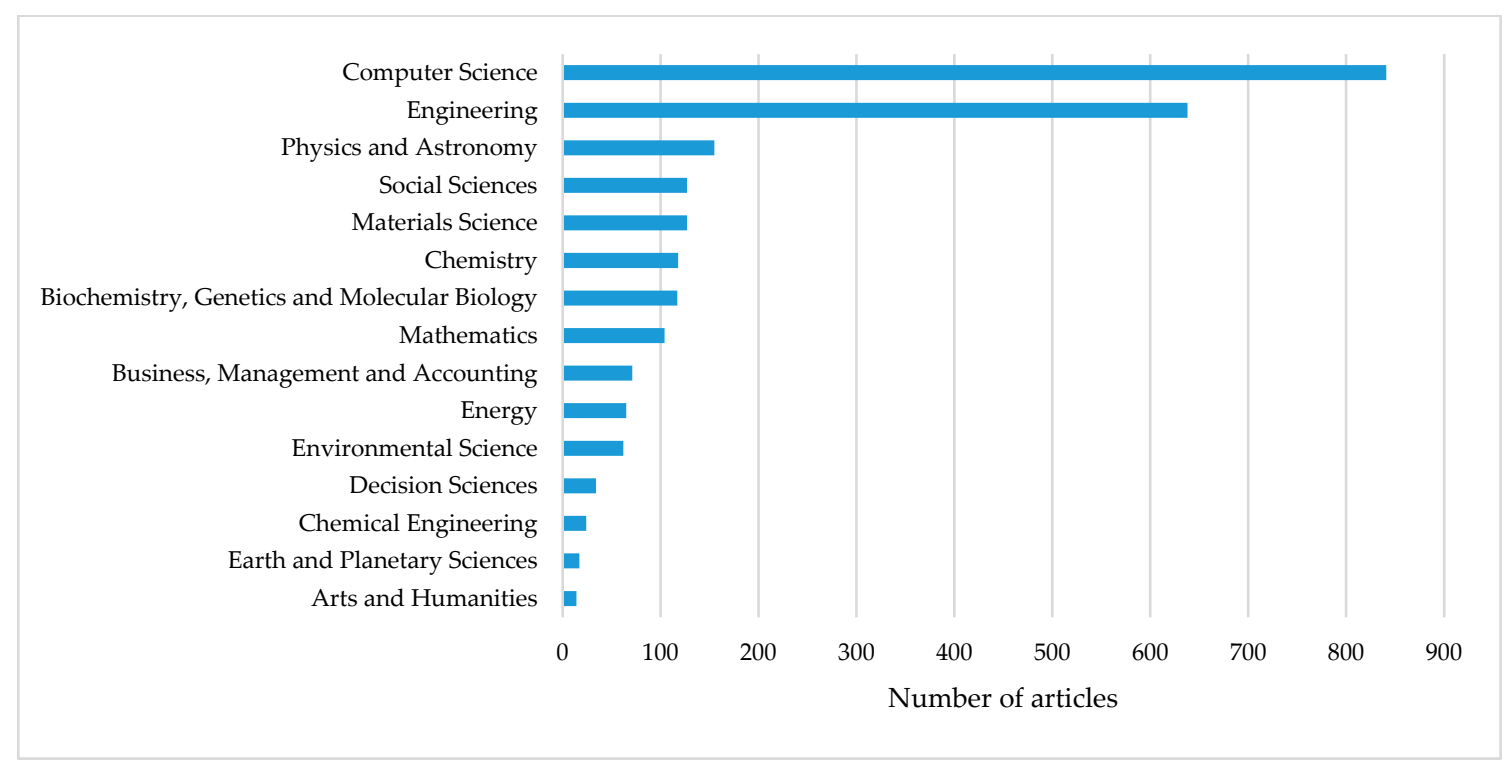

Figure 3. Top 15 subject areas (2011-2019).

Computer Science is the category that collects the most articles $(68.10 \%, 839$ articles published), followed by Engineering $(51.79 \%, 638)$. Next, they are followed by Physics and Astronomy $(12.58 \%, 155)$, Materials Science $(10.31 \%, 127)$, Social Sciences $(10.31 \%, 127)$, Chemistry $(9.58 \%, 118)$, Biochemistry, Genetics, and Molecular Biology $(9.50 \%, 117)$, Mathematics $(8.44 \%, 104)$, Business, Management, and Accounting $(5.76 \%, 71)$, Energy $(5.28 \%, 65)$, and Environmental Science $(5.03 \%, 62)$. The rest of subject areas do not reach $2 \%$ each of the published documents.

The phenomenon of the transformation of urban environments into smart cities is the subject of multidisciplinary research. Its analysis is complex, since its evolution is the reflection of numerous disciplines [118]. Although in a subject related from its origin to computer science and engineering, it is also linked by its repercussions with the social sciences, the economy, health, or urban planning [119].

Table 2 displays the main characteristics of the 10 most productive scientific journals on the research topic in the 2011-2019 period: number of articles, number of citations for all articles, number of citations by article, country, subject area, h-index in this research topic, Scopus main quality metrics (CiteScore, SJR and SNIP), and year of the first and last published article. 
Table 2. Top 10 journals (2011-2019).

\begin{tabular}{|c|c|c|c|c|c|c|c|c|c|c|c|}
\hline Journal & A & C & C/A & Country & Subject Area & $h^{*}$ & Citescore* & $\mathrm{SJR} *$ & $\underset{*}{\mathrm{SNIP}}$ & $1 A^{*}$ & LA * \\
\hline Sensors & 101 & 1112 & 0.901 & Switzerland & BGM-CH-EN-PA & 23 & 3.72 & 0.592 & 1.576 & 2013 & 2019 \\
\hline IEEE Access & 92 & 1408 & 1.141 & USA & CS-EN-PA & 20 & 4.96 & 0.609 & 1.718 & 2015 & 2019 \\
\hline $\begin{array}{l}\text { IEEE Internet of } \\
\text { Things Journal }\end{array}$ & 80 & 4774 & 3.869 & USA & CS & 25 & 11.33 & 1.396 & 3.874 & 2014 & 2019 \\
\hline $\begin{array}{l}\text { Future Generation } \\
\text { Computer Systems } \\
\end{array}$ & 66 & 2362 & 1.914 & Netherlands & CS & 25 & 6.30 & 0.835 & 2.464 & 2016 & 2019 \\
\hline $\begin{array}{l}\text { IEEE Communications } \\
\text { Magazine }\end{array}$ & 24 & 843 & 0.683 & USA & CS-EN & 15 & 11.27 & 2.373 & 4.681 & 2013 & 2019 \\
\hline $\begin{array}{l}\text { International Journal } \\
\text { of Innovative } \\
\text { Technology and } \\
\text { Exploring Engineering }\end{array}$ & 23 & 0 & 0.000 & India & CS-EN & 1 & NA & NA & NA & 2019 & 2019 \\
\hline $\begin{array}{l}\text { Sustainable Cities and } \\
\text { Society }\end{array}$ & 17 & 283 & 0.229 & Netherlands & EY-EN-SS & 9 & 5.22 & 1.100 & 1.745 & 2017 & 2019 \\
\hline $\begin{array}{l}\text { International Journal } \\
\text { of Recent Technology } \\
\text { and Engineering }\end{array}$ & 16 & 3 & 0.002 & India & BMA-EN & 1 & NA & $\mathrm{NA}$ & $\mathrm{NA}$ & 2018 & 2019 \\
\hline Sustainability & 16 & 86 & 0.070 & Switzerland & EY-ES-SS & 7 & 3.01 & 0.549 & 1.169 & 2016 & 2019 \\
\hline $\begin{array}{l}\text { International Journal } \\
\text { of Advanced } \\
\text { Computer Science and } \\
\text { Applications }\end{array}$ & 13 & 9 & 0.007 & UK & CS & 2 & NA & NA & NA & 2018 & 2019 \\
\hline $\begin{array}{l}\text { A: number of ar } \\
\text { and Molecular B } \\
\text { Energy; SS: Soci } \\
\text { or Hirsch index; } \\
\text { Impact per Pape }\end{array}$ & ניני & s; BN & ition & $\begin{array}{l}\text { C/A: averag } \\
\text {; EN: Engine } \\
\text { ness, Manage }\end{array}$ & $\begin{array}{l}\text { number of citat } \\
\text { meng; PA: Physic } \\
\text { ment and Accou }\end{array}$ & $\mathrm{s}$ p & $\begin{array}{l}\text { article; BG } \\
\text { stronomy; } \\
\text { S: Environ }\end{array}$ & $\begin{array}{l}\text { Bioch } \\
\text { Comy } \\
\text { ental Sc }\end{array}$ & $\begin{array}{l}\text { mistry, } \\
\text { uter Sc } \\
\text { lence; h }\end{array}$ & $\begin{array}{l}\text { Geneti } \\
\text { ence; } \\
\text { h-ind }\end{array}$ & \\
\hline
\end{tabular}

According the number of articles published and the percentage they represent of the total sample, this ranking is led by Sensors $(101,8.18 \%)$, followed by IEEE Access $(92,7.46 \%)$. Both are followed by, in order, The IEEE Internet of Things Journal (6.48\%) and Future Generation Computer Systems $(5.35 \%)$. The rest of the journals in this ranking do not exceed $2 \%$ of the total. It highlights that $50 \%$ of these journals are of European origin (2 Swiss, 2 Dutch and 1 British), while 30\% are North American and $20 \%$ are Indian.

The variety of the countries of the most outstanding journals is related to a set of socioeconomic factors existing in the context where the scientific activity is carried out, such as: investment for research and development (R\&D), gross domestic product (GDP), economically active population (PEA), number of researchers, etc. Other factors such as cultural factors, the influence of educational systems, historical tradition, the scientific policies of governments, and the development of private companies also influence. All this allows certain regions and countries to excel in investments and R\&D budgets with their consequent results in scientific advances. In this globalized and increasingly technological world, scientific production, publishers, journals, and readers are distributed heterogeneously throughout the world $[10,31,38]$.

Moreover, The IEEE Internet of Things Journal ( 80 articles) is the journal with the most citations (4774), and the highest average number of citations per article (3.869), despite the fact that it has been publishing articles on this topic for only 6 years. It is followed by the Dutch Future Generation Computer Systems $(2362,1.914)$, which published its first article on IoT in smart city research in 2016. These two journals present the highest h-index in the ranking with 25.

The Computer Science and Engineering subject areas are the most outstanding, just as it happens in the total computation (see Figure 4), since 6 journals classify their articles in these. They are followed by Physics and Astronomy and Energy and Social Sciences with 2 journals each. This aspect reveals that the articles on smart cities based on IoT technology applications are classified in a wide range of subject areas, in addition to Computer Science and Engineering. 


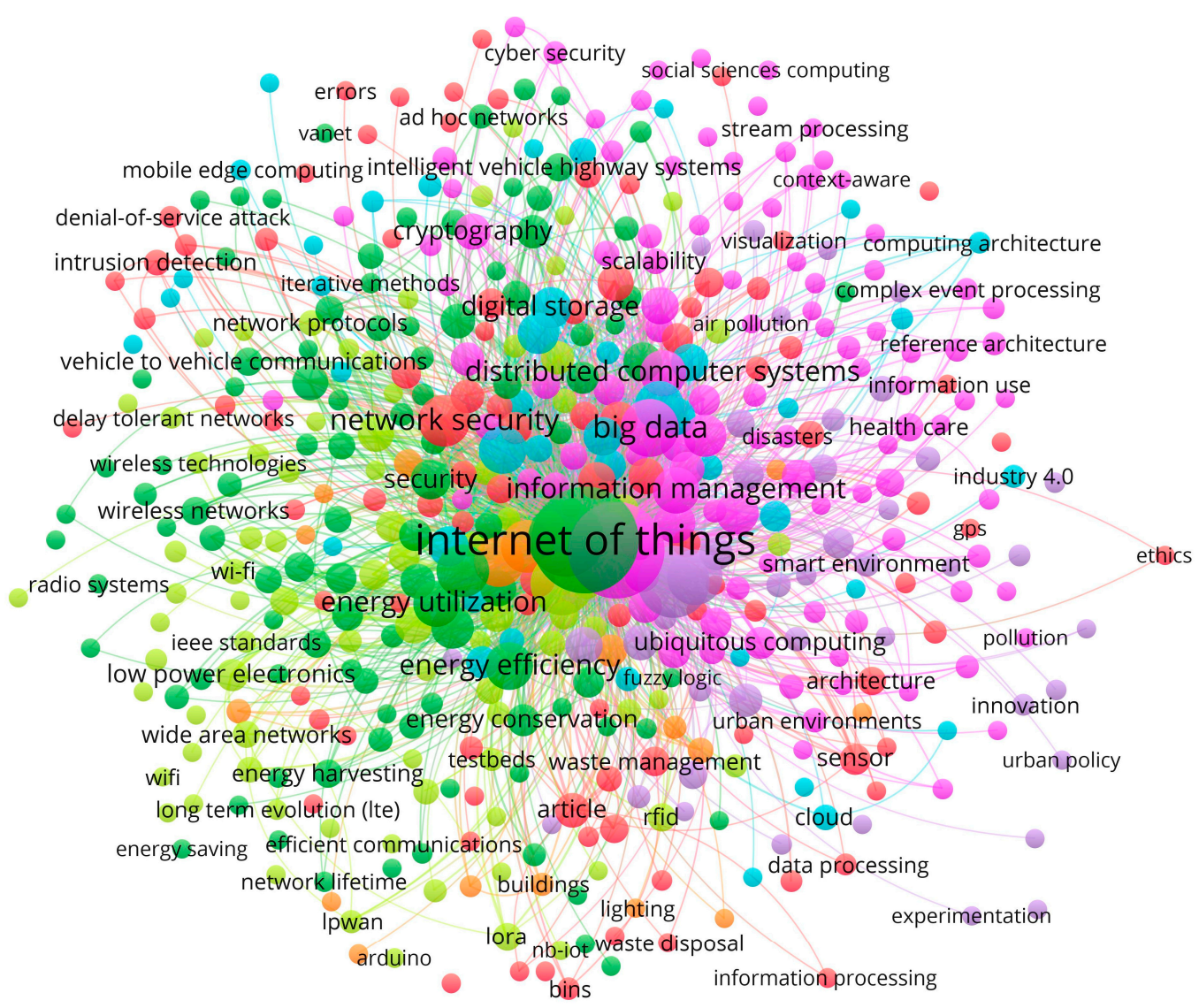

Figure 4. Keywords network based on the co-occurrence method (2011-2019).

On the other hand, Table 2 includes for the top 10 journals the main impact metrics of 2018 suggested by Scopus database: CiteScore, SCImago Journal Rank (SJR), and Source Normalized Impact per Paper (SNIP).

Likewise, it is very remarkable, due to the interest generated by research on smart cities based on IoT technology applications in the international scientific community, which are the 10 most productive journals published in 2019.

The North American IEEE Internet of Things Journal (11.33) and IEEE Communications Magazine (11.27) were the journals with the highest CiteScore. The latter, IEEE Communications Magazine, was also the journal with the highest SJR (2.373) and SNIP (4.681).

It also highlights that 3 journals (International Journal of Innovative Technology and Exploring Engineering, International Journal of Recent Technology and Engineering, and International Journal of Advanced Computer Science and Applications) have not been able to calculate the metrics due to their recent incorporation into the study theme.

Besides, the first article was published in 2011, titled "Smart Cities at the Forefront of the Future Internet", and written by Hernández-Muñoz, J. M., Vercher, J. B., Muñoz, L., Galache, J. A., Presser, M., Hernández Gómez, L. A. and Pettersson, J., in Lecture Notes in Computer Science. It currently has 207 citations [120]. Likewise, the most cited article (2387) was published in 2014, titled "Internet of Things for Smart Cities", written by Zanella, A.; Bui, N., Castellani, A., Vangelista, L., and Zorzi, M., in IEEE Internet of Things Journal [121].

\subsection{Keyword Analysis}

Section 4.3 presents a keyword analysis on researching smart cities based on IoT technology applications from 2011 to 2019. From this analysis, the main lines of research carried out globally in this period have been detected. 
Thereby, Table 3 lists, according to the Scopus database, the 20 most frequently used keywords in the 1232 articles of the analyzed sample. The most prominent terms are "Internet of Things" (in 901 articles, 73.01\%) and "Smart City" (654, 53\%). These two keywords were considered in the search query for the Scopus database. Similar terms to the main ones appear in the following positions: Smart Cities (280, 22.69\%), Internet of Things (IoT) $(269,21.80 \%)$, and IoT $(171,13.86 \%)$.

Table 3. Top 20 keywords (2011-2019).

\begin{tabular}{ccccccc}
\hline Rank & Keyword & Articles & $\%$ & Links & $\begin{array}{c}\text { Total Link } \\
\text { Strength }\end{array}$ & $\begin{array}{c}\text { Cluster } \\
\text { (See Figure 4) }\end{array}$ \\
\hline 1 & Internet of Things & 901 & $73.13 \%$ & 493 & 6811 & 2 \\
2 & Smart City & 654 & $53.08 \%$ & 489 & 5068 & 1 \\
3 & Big Data & 147 & $11.93 \%$ & 335 & 1355 & 1 \\
4 & Internet & 126 & $10.23 \%$ & 273 & 989 & 5 \\
5 & Wireless Sensor Networks & 111 & $9.01 \%$ & 304 & 1059 & 2 \\
6 & Automation & 105 & $8.52 \%$ & 306 & 1071 & 7 \\
7 & Network Security & 97 & $7.87 \%$ & 287 & 962 & 3 \\
8 & Intelligent Buildings & 95 & $7.71 \%$ & 280 & 979 & 7 \\
9 & Cloud Computing & 88 & $7.14 \%$ & 249 & 799 & 6 \\
10 & Energy Efficiency & 80 & $6.49 \%$ & 262 & 841 & 2 \\
11 & Network Architecture & 78 & $6.33 \%$ & 259 & 831 & 6 \\
12 & Information Management & 74 & $6.01 \%$ & 266 & 780 & 1 \\
13 & Distributed Computer Systems & 72 & $5.84 \%$ & 243 & 729 & 1 \\
14 & Energy Utilization & 72 & $5.84 \%$ & 246 & 696 & 2 \\
15 & Data Handling & 57 & $4.63 \%$ & 214 & 590 & 1 \\
16 & Sensors & 55 & $4.46 \%$ & 194 & 456 & 1 \\
17 & Fog Computing & 53 & $4.30 \%$ & 176 & 501 & 6 \\
18 & Digital Storage & 51 & $4.14 \%$ & 191 & 485 & 6 \\
19 & Decision Making & 50 & $4.06 \%$ & 199 & 476 & 1 \\
20 & Security & 49 & $3.98 \%$ & 162 & 391 & 2 \\
\hline
\end{tabular}

The other keywords in these top 20 are grouped around thematic disciplines such as data intelligence-Big Data (147, 11.91\%), Information Management (74,6.00\%) and Data Handling (57, 4.62\%); Networks and sensors: Wireless Sensor Networks (111, 9\%), Network Security (97, 7.86\%), Network Architecture (78, 6.32\%), Sensors (55, 4.46\%) and Sensor Nodes (54, 4.38\%); computing-Internet (126, 10.21\%), Automation (105, 8.51\%), Cloud Computing (88, 7.13\%), Distributed Computer Systems (72, 5.83\%); and architecture and urbanism-Intelligent Buildings (95, 7.70\%), Energy Efficiency (80, 6.48\%), and Energy Utilization (72, 5.83\%).

The research theme of this study requires an interdisciplinary and transversal effort. The relatively recent emergence of this research field means that it is studied from different perspectives, both technical and social, that promote the emergence of new terms at an international level associated with this scientific approach $[122,123]$.

The VOSviewer tool provides the data for the link and the total link strength attributes. The first denotes a co-occurrence connection between two keywords, while the second indicates the number of posts in which two keywords appear together. Thus, the "Internet of Things" is the one with more links (732) and more total link strength (6811), followed by "Smart City" $(489,5068)$. Among the similar terms, the criterion that follows has been to quantify only the one that is present in a greater number of articles, in order to avoid the software grouping them into different clusters.

Figure 4 represents the network map for the keywords of the articles on this research topic, which is based on the co-occurrence method. The color of the nodes is used to distinguish the different clusters based on the number of co-occurrences, while the size varies according to the number of repetitions.

VOSviewer software has identified in seven main lines of research from the different keyword communities on smart cities based on IoT technology applications. The keyword with the largest 
number of articles within each cluster has allowed us to name and define the research axis and on which the rest of the terms are associated. These are "Smart City", "Internet of Things", "Network Security", "Wireless Telecommunication Systems", "Internet", "Cloud Computing", and "Automation". For each of the terms, the occurrences attribute is indicated, which denotes the number of documents in which a term appears, and the total strength of the link, which, as previously commented, refers to the number of publications in which two terms appear together.

Cluster 1 (pink color) is led by "Smart City" (occurrences: 655, links: 489, total link strength: 5068 ) and groups $21.86 \%$ of the keywords. Table 4 contains the 20 main keywords associated with this cluster. This first thematic axis studies the holistic vision of the city that applies new technologies to increase the quality of life and accessibility of its citizens, while considering sustainable development. This interconnected system manages transport systems, the efficient use of energy or water resources, socio-economic aspects, security in public spaces, and the commercial fabric, or effective communication $[124,125]$.

Table 4. Cluster 1: Top 20 keywords (2011-2019).

\begin{tabular}{lccccccccc}
\hline $\mathbf{R}$ & Keyword & $\mathbf{O}$ & $\mathbf{L}$ & $\mathbf{T L S}$ & $\mathbf{R}$ & Keyword & O & L & TLS \\
\hline 1 & Big Data & 147 & 335 & 1355 & 11 & Semantics & 32 & 122 & 260 \\
\hline 2 & $\begin{array}{c}\text { Information } \\
\text { Management }\end{array}$ & 74 & 266 & 780 & 12 & Data Acquisition & 30 & 150 & 315 \\
\hline 3 & $\begin{array}{c}\text { Distributed Computer } \\
\text { Systems }\end{array}$ & 72 & 243 & 729 & 13 & Data Analytics & 28 & 138 & 292 \\
\hline 4 & Data Handling & 57 & 214 & 590 & 14 & Middleware & 28 & 124 & 227 \\
\hline 5 & Sensors & 55 & 194 & 456 & 15 & Environmental Monitoring & 27 & 120 & 221 \\
\hline 6 & Decision Making & 50 & 199 & 476 & 16 & Ubiquitous Computing & 26 & 126 & 235 \\
\hline 7 & Monitoring & 45 & 186 & 431 & 17 & Privacy & 23 & 113 & 220 \\
\hline 8 & Data Privacy & 37 & 177 & 418 & 18 & Proposed Architectures & 23 & 134 & 288 \\
\hline 9 & Cryptography & 35 & 148 & 345 & 19 & Application Programs & 21 & 125 & 204 \\
\hline 10 & $\begin{array}{c}\text { Information and } \\
\text { Communication } \\
\text { Technologies }\end{array}$ & 32 & 170 & 335 & 20 & Smartphones & 20 & 119 & 192 \\
\hline
\end{tabular}

R: Rank position; O: Occurrences; L: Links; TLS: Total Link Strength.

Cluster 2 (green color) groups $21.26 \%$ of the main terms and is headed by "Internet of Things" (occurrences: 902, link: 493, total link strength: 6811). Table 5 contains the 20 main keywords associated with this cluster. This second thematic axis studies the network of physical objects that uses sensors and application programming interfaces to connect and exchange data over the Internet, together with Big Data management tools, predictive analytics, radio frequency identification, AI and machine learning, or the cloud [126,127]. 
Table 5. Cluster 2: Top 20 keywords (2011-2019).

\begin{tabular}{cccccccccc}
\hline $\mathbf{R}$ & Keyword & O & L & TLS & R & Keyword & O & L & TLS \\
\hline 1 & $\begin{array}{c}\text { Wireless Sensor } \\
\text { Networks }\end{array}$ & 111 & 304 & 1059 & 11 & $\begin{array}{c}\text { Intelligent Transportation } \\
\text { Systems }\end{array}$ & 29 & 136 & 310 \\
\hline 2 & Energy Efficiency & 81 & 262 & 841 & 12 & Energy Conservation & 26 & 124 & 250 \\
\hline 3 & Energy Utilization & 72 & 246 & 696 & 13 & Complex Networks & 25 & 141 & 239 \\
\hline 4 & Security & 49 & 162 & 391 & 14 & $\begin{array}{c}\text { Mobile Telecommunication } \\
\text { Systems }\end{array}$ & 23 & 121 & 210 \\
\hline 5 & Intelligent Systems & 43 & 178 & 437 & 15 & Scheduling & 22 & 118 & 212 \\
\hline 6 & Authentication & 35 & 113 & 317 & 16 & Wireless Sensor Network & 21 & 120 & 205 \\
\hline 7 & Optimization & 33 & 147 & 268 & 17 & Gateways (Computer & 20 & 99 & 205 \\
\hline 8 & Vehicles & 32 & 154 & 343 & 18 & Wireless Sensor Network \\
(WSNS) & 18 & 75 & 161 \\
\hline 9 & $\begin{array}{c}\text { 5G Mobile } \\
\text { Communication } \\
\text { Systems }\end{array}$ & 30 & 141 & 265 & 19 & Energy Harvesting & 17 & 79 & 140 \\
\hline 10 & $\begin{array}{c}\text { Intelligent } \\
\text { Transportation } \\
\text { Systems }\end{array}$ & 29 & 136 & 310 & 20 & Traffic Congestion & 17 & 108 & 178 \\
\hline
\end{tabular}

R: Rank position; O: Occurrences; L: Links; TLS: Total Link Strength.

Cluster 3 (red color) is led by "Network Security" (occurrences: 97, link: 287, total link strength: 962), and it groups $18.83 \%$ of the keywords. Table 6 contains the 20 main keywords associated with this cluster. This third research line looks at network security that ensures the integrity, availability, and performance of an organization through the protection of IT assets against cyber threats. Thereby, it is a key component of network optimization, to prevent attacks and increase the productivity of companies $[128,129]$.

Table 6. Cluster 3: Top 20 keywords (2011-2019).

\begin{tabular}{|c|c|c|c|c|c|c|c|c|c|}
\hline $\mathbf{R}$ & Keyword & $\mathbf{O}$ & $\mathbf{L}$ & TLS & $\mathbf{R}$ & Keyword & $\mathbf{O}$ & $\mathbf{L}$ & TLS \\
\hline 1 & Machine Learning & 40 & 176 & 385 & 11 & Transportation & 20 & 117 & 216 \\
\hline 2 & Data Mining & 39 & 143 & 331 & 12 & Waste Management & 20 & 84 & 168 \\
\hline 3 & Artificial Intelligence & 33 & 164 & 317 & 13 & Air Quality & 18 & 83 & 157 \\
\hline 4 & Learning Systems & 33 & 177 & 356 & 14 & Architecture & 17 & 84 & 144 \\
\hline 5 & Sensor Networks & 30 & 132 & 241 & 15 & Neural Networks & 16 & 82 & 153 \\
\hline 6 & Deep Learning & 28 & 131 & 266 & 16 & Sensors and Actuators & 16 & 89 & 144 \\
\hline 7 & Real Time Systems & 26 & 154 & 293 & 17 & Security of Data & 15 & 75 & 128 \\
\hline 8 & Forecasting & 21 & 90 & 179 & 18 & Urban Transportation & 14 & 68 & 123 \\
\hline 9 & Learning Algorithms & 20 & 112 & 213 & 19 & Economic and Social Effects & 13 & 89 & 122 \\
\hline 10 & Security Systems & 20 & 100 & 189 & 20 & Interactive Computer Systems & 13 & 90 & 151 \\
\hline
\end{tabular}

R: Rank position; O: Occurrences; L: Links; TLS: Total Link Strength.

Cluster 4 (yellow color) associates $17 \%$ of the main keywords and is headed by "Wireless Telecommunication Systems" (occurrences: 40, link: 185, total link strength: 450). Table 7 contains the 20 main keywords associated with this cluster. The fourth thematic axis develops a macroscopic approach to wireless telecommunications systems through specific analyses related to power, data rates, multiple access, cellular engineering, and access network architectures $[130,131]$. 
Table 7. Cluster 4. Top 20 keywords (2011-2019).

\begin{tabular}{cccccccccc}
\hline $\mathbf{R}$ & Keyword & O & L & TLS & $\mathbf{R}$ & Keyword & O & L & TLS \\
\hline 1 & Internet Protocols & 34 & 160 & 357 & 12 & $\begin{array}{c}\text { Long Range Technology } \\
\text { (LORA) }\end{array}$ & 17 & 62 & 130 \\
\hline 2 & Embedded Systems & 29 & 153 & 306 & 13 & Network Layers & 17 & 110 & 185 \\
\hline 3 & $\begin{array}{c}\text { Radio Frequency } \\
\text { Identification (RFID) }\end{array}$ & 27 & 125 & 228 & 14 & Cost Effectiveness & 16 & 100 & 166 \\
\hline 4 & Low Power Electronics & 25 & 132 & 279 & 15 & IoT Architectures & 15 & 81 & 132 \\
\hline 5 & Smart Power Grids & 23 & 129 & 261 & 16 & Zigbee & 15 & 78 & 120 \\
\hline 6 & $\begin{array}{c}\text { Communication } \\
\text { Technologies }\end{array}$ & 22 & 123 & 211 & 17 & Wide Area Networks & 14 & 90 & 181 \\
\hline 7 & $\begin{array}{c}\text { Electric Power } \\
\text { Transmission } \\
\text { Networks }\end{array}$ & 22 & 138 & 263 & 18 & LoRaWAN & 13 & 65 & 120 \\
\hline 8 & Smart Grid & 22 & 126 & 233 & 19 & Standards & 13 & 77 & 114 \\
\hline 9 & $\begin{array}{c}\text { Wireless } \\
\text { Communications }\end{array}$ & 19 & 120 & 209 & 20 & Wi-Fi & 13 & 93 & 146 \\
\hline 10 & $\begin{array}{c}\text { Radio Frequency } \\
\text { Identification (RFID) }\end{array}$ & 18 & 103 & 209 & 20 & $\begin{array}{c}\text { Message Queue Telemetry } \\
\text { Transport (MQTT) }\end{array}$ & 12 & 31 & 49 \\
\hline
\end{tabular}

R: Rank position; O: Occurrences; L: Links; TLS: Total Link Strength.

Cluster 5 (purple color) is led by “Internet" (occurrences: 126, link: 273, total link strength: 989), and it groups $8.91 \%$ of the keywords. Table 8 contains the 20 main keywords associated with this cluster. The fifth research line has developed contributions on the concept of "Internet" in relation to smart cities based on IoT technology applications, as a decentralized set of interconnected communication networks that use the Transmission Control Protocol/Internet Protocol (TCP/IP), guaranteeing that the heterogeneous physical networks that comprise it constitute a unique logical global network [132,133].

Table 8. Cluster 5: Top 20 keywords (2011-2019).

\begin{tabular}{cccccccccc}
\hline $\mathbf{R}$ & Keyword & O & L & TLS & $\mathbf{R}$ & Keyword & O & L & TLS \\
\hline 1 & Interoperability & 38 & 145 & 301 & 11 & Smart Environment & 13 & 68 & 104 \\
2 & IoT Applications & 31 & 107 & 215 & 12 & $\begin{array}{c}\text { Information and } \\
\text { Communication Technology }\end{array}$ & 12 & 35 & 70 \\
& Sustainable & 29 & 131 & 264 & 13 & Ecology & 11 & 68 & 113 \\
3 & Development & & & & & & \\
& & & & & & & \\
4 & Urban Growth & 27 & 131 & 272 & 14 & Mobility & 11 & 38 & 63 \\
5 & Semantic Web & 23 & 99 & 195 & 15 & Energy & 11 & 57 & 85 \\
6 & Urban Planning & 22 & 93 & 184 & 16 & 10 & 62 & 101 \\
7 & Electronic Commerce & 21 & 76 & 152 & 17 & Technological Development & 9 & 33 & 54 \\
8 & Ecosystems & 18 & 113 & 189 & 18 & 5 G & 8 & 46 & 58 \\
9 & Population Statistics & 18 & 99 & 173 & 19 & Building Blocks & 8 & 33 & 47 \\
10 & Sustainability & 16 & 79 & 146 & 20 & Innovation & 8 & 25 & 43 \\
\hline
\end{tabular}

R: Rank position; O: Occurrences; L: Links; TLS: Total Link Strength.

Cluster 6 (cyan color) is led by "Cloud Computing" (occurrences: 88, link: 249, total link strength: 799, ), and it groups $8.70 \%$ of the keywords. Table 9 contains the 20 main keywords associated with this cluster. The sixth thematic axis develops studies on cloud computing, in relation to the availability upon request of the resources of the computer system, such as data storage and computing capacity, without direct active management by the user. This keyword represents the data centers available from anywhere over the Internet from any mobile or fixed device [134,135]. 
Table 9. Cluster 6. Top 20 keywords (2011-2019).

\begin{tabular}{|c|c|c|c|c|c|c|c|c|c|}
\hline $\mathbf{R}$ & Keyword & $\mathbf{O}$ & $\mathbf{L}$ & TLS & $\mathbf{R}$ & Keyword & $\mathbf{O}$ & $\mathbf{L}$ & TLS \\
\hline 1 & Network Architecture & 78 & 259 & 831 & 11 & Resource Management & 15 & 88 & 159 \\
\hline 2 & Fog Computing & 53 & 176 & 501 & 12 & Telecommunication Services & 14 & 90 & 138 \\
\hline 3 & Digital Storage & 51 & 191 & 485 & 13 & Cloud & 13 & 53 & 87 \\
\hline 4 & Quality of Service & 47 & 218 & 464 & 14 & Software Defined Networking & 13 & 100 & 162 \\
\hline 5 & Edge Computing & 44 & 179 & 445 & 15 & Web Services & 12 & 56 & 95 \\
\hline 6 & Fog & 40 & 153 & 419 & 16 & Augmented Reality & 11 & 63 & 90 \\
\hline 7 & $\begin{array}{l}\text { Computer } \\
\text { Architecture }\end{array}$ & 37 & 177 & 445 & 17 & Heterogeneous Devices & 11 & 72 & 107 \\
\hline 8 & Blockchain & 26 & 101 & 194 & 18 & Energy Consumption & 10 & 73 & 104 \\
\hline 9 & Green Computing & 25 & 157 & 306 & 19 & Industry 4.0 & 10 & 38 & 49 \\
\hline 10 & Information Services & 23 & 140 & 263 & 20 & Mobile Devices & 10 & 59 & 83 \\
\hline
\end{tabular}

R: Rank position; O: Occurrences; L: Links; TLS: Total Link Strength.

Finally, cluster 7 (orange color) associates $3.44 \%$ of the main terms and is headed by "Automation" (link: 306, total link strength: 1071, occurrences: 105). Table 10 contains the 20 main keywords associated with this cluster. The seventh line of research contributes to developing automation, with reference to the system that allows a machine to carry out certain processes or perform tasks without human intervention, guaranteeing time and cost savings [136,137].

Table 10. Cluster 7: Top 20 keywords (2011-2019).

\begin{tabular}{|c|c|c|c|c|c|c|c|c|c|}
\hline $\mathbf{R}$ & Keyword & $\mathbf{O}$ & $\mathbf{L}$ & TLS & $\mathbf{R}$ & Keyword & $\mathbf{O}$ & $\mathbf{L}$ & TLS \\
\hline 1 & Intelligent Buildings & 95 & 280 & 979 & 11 & Lighting & 6 & 43 & 55 \\
\hline 2 & Smart Homes & 26 & 106 & 250 & 12 & $\begin{array}{l}\text { Wireless Sensor Networks } \\
\text { (WSN) }\end{array}$ & 6 & 30 & 44 \\
\hline 3 & Energy Management & 17 & 90 & 178 & 13 & Building Management System & 5 & 37 & 56 \\
\hline 4 & $\begin{array}{l}\text { Energy Management } \\
\text { Systems }\end{array}$ & 11 & 54 & 96 & 14 & Energy Optimization & 5 & 40 & 54 \\
\hline 5 & Buildings & 10 & 64 & 119 & 15 & Light-Emitting Diodes & 5 & 32 & 41 \\
\hline 6 & Future Internet & 10 & 48 & 73 & 16 & Security Requirements & 6 & 29 & 49 \\
\hline 7 & Smart Building & 8 & 47 & 86 & 17 & $\begin{array}{l}\text { Service-Oriented Architecture } \\
\text { (SOA) }\end{array}$ & 6 & 42 & 65 \\
\hline 8 & Commerce & 7 & 48 & 63 & 18 & Control Systems & 5 & 28 & 38 \\
\hline 9 & Architectural Design & 6 & 29 & 36 & 19 & Realtime Processing & 5 & 50 & 60 \\
\hline 10 & Cameras & 6 & 33 & 43 & 20 & Electronic Data Interchange & 5 & 50 & 59 \\
\hline
\end{tabular}

R: Rank position; O: Occurrences; L: Links; TLS: Total Link Strength.

These research lines identified bring together all the concepts related to smart cities based on IoT technology applications global research, during the 2011-2019 period. In other words, these thematic axes include the different approaches analyzed by the different actors (authors, research institutions and countries) that make up this research field.

\subsection{Analysis of Authors, Research Institutions, and Countries}

Section 4.4 shows the thematic areas in which the articles and the main keywords of the authors, research institutions, and most productive countries are classified. Likewise, their collaboration networks are shown, based on co-authorship analysis.

\subsubsection{Authors}

Table 11 shows the main characteristics of the 10 most prolific authors in this research topic. The sample of articles has been written by 3744 authors. 
Table 11. Top 10 authors and main keywords (2011-2019).

\begin{tabular}{|c|c|c|c|c|c|c|c|c|c|c|c|c|}
\hline Author & Institution & $\mathbf{A}$ & Country & SA & $\mathrm{C}$ & C/A & $\mathbf{h}^{*}$ & $1 \mathrm{~A} *$ & LA * & Keyword 1 & Keyword 2 & Keyword 3 \\
\hline Muñoz, L. & $\begin{array}{l}\text { Universidad } \\
\text { de Cantabria }\end{array}$ & 10 & Spain & CS-E & 618 & 62 & 8 & 2011 & 2019 & Internet & $\begin{array}{l}\text { Electronic } \\
\text { Commerce }\end{array}$ & Experimentation \\
\hline Choo, K.K.R. & $\begin{array}{l}\text { University of } \\
\text { Texas at San } \\
\text { Antonio }\end{array}$ & 9 & USA & CS & 169 & 19 & 6 & 2016 & 2019 & $\begin{array}{l}\text { Cloud } \\
\text { computing }\end{array}$ & $\begin{array}{l}\text { Digital } \\
\text { Storage }\end{array}$ & Blockchain \\
\hline Kantarci, B. & $\begin{array}{l}\text { University of } \\
\text { Ottawa }\end{array}$ & 9 & Canada & CS-MA & 155 & 17 & 7 & 2016 & 2019 & $\begin{array}{c}\text { Mobile } \\
\text { Crowdsensing }\end{array}$ & $\begin{array}{c}\text { Data } \\
\text { Acquisition }\end{array}$ & Crowdsensing \\
\hline Al-Turjman, F. & $\begin{array}{l}\text { Antalya Bilim } \\
\text { University }\end{array}$ & 8 & Turkey & CS-E & 111 & 14 & 6 & 2018 & 2019 & $\begin{array}{l}\text { Energy } \\
\text { Utilization }\end{array}$ & $\begin{array}{l}\text { Extensive } \\
\text { Simulations }\end{array}$ & $\begin{array}{l}\text { Power Management } \\
\text { (telecommunication) }\end{array}$ \\
\hline Park, J.H. & $\begin{array}{l}\text { Seoul National } \\
\text { University of } \\
\text { Science and } \\
\text { Technology }\end{array}$ & 8 & $\begin{array}{l}\text { South } \\
\text { Korea }\end{array}$ & CS-EY & 163 & 20 & 5 & 2017 & 2019 & $\begin{array}{l}\text { Network } \\
\text { Architecture }\end{array}$ & Blockchain & Network Security \\
\hline Santana, J.R. & $\begin{array}{l}\text { Universidad } \\
\text { de Cantabria }\end{array}$ & 8 & Spain & E-CS & 383 & 48 & 6 & 2012 & 2019 & Internet & Testbed & $\begin{array}{l}\text { Electronic } \\
\text { Commerce }\end{array}$ \\
\hline Barnaghi, P. & $\begin{array}{l}\text { UK Dementia } \\
\text { Research } \\
\text { Institute }\end{array}$ & 7 & UK & CS-E & 148 & 21 & 6 & 2015 & 2019 & Data Mining & Semantics & Data Analytics \\
\hline Guizani, M. & $\begin{array}{c}\text { Qatar } \\
\text { University }\end{array}$ & 7 & Qatar & CS-E & 99 & 14 & 6 & 2017 & 2019 & $\begin{array}{c}\text { 5G Mobile } \\
\text { Communication } \\
\text { Systems }\end{array}$ & Blockchain & $\begin{array}{l}\text { Device-to-Device } \\
\text { Communications }\end{array}$ \\
\hline Sotres, P. & $\begin{array}{l}\text { Universidad } \\
\text { de Cantabria }\end{array}$ & 7 & Spain & CS-E & 378 & 54 & 5 & 2012 & 2019 & $\begin{array}{l}\text { Network } \\
\text { Architecture }\end{array}$ & $\begin{array}{l}\text { Electronic } \\
\text { Commerce }\end{array}$ & $\begin{array}{l}\text { Information and } \\
\text { Communication } \\
\text { Technologies }\end{array}$ \\
\hline Zaslavsky, A. & $\begin{array}{l}\text { Deakin } \\
\text { University }\end{array}$ & 7 & Australia & CS-E & 583 & 83 & 5 & 2014 & 2019 & $\begin{array}{c}\text { Waste } \\
\text { Management }\end{array}$ & Internet & Waste Disposal \\
\hline
\end{tabular}

A: number of articles; SA: subject areas; CS: Computer Science; EN: Engineering; MA: Mathematics; EY: Energy; C: total citations; C/A: average number of citations per article; h: h-index or Hirsch index; 1A: first article; LA: last article; $\left(^{*}\right)$ in this research topic.

Hence, the 10 most productive authors and the research institutions to which they are affiliated were Muñoz, L. (Network Planning and Mobile Communications Laboratory, Universidad de Cantabria, Santander, Spain); Choo, K.K.R. (Department of Information Systems and Cyber Security, University of Texas at San Antonio, San Antonio, TX, USA); Kantarci, B. (School of Electrical Engineering and Computer Science, University of Ottawa, Ottawa, ON, Canada); Al-Turjman, F. (Antalya Bilim University, Antakya, Turkey); Park, J.H. (Seoul National University of Science and Technology—SNUST, Seoul, South Korea); Santana, J.R. (Network Planning and Mobile Communications Laboratory, Universidad de Cantabria, Santander, Spain); Barnaghi, P. (UK Dementia Research Institute, Care Research and Technology Centre, London, UK; Centre for Vision, Speech and Signal Processing, University of Surrey, Guildford, UK); Guizani, M. (Department of Computer Science and Engineering, Qatar University, Doha, Qatar); Sotres, P. (Network Planning and Mobile Communications Laboratory, Universidad de Cantabria, Santander, Spain); and Zaslavsky, A. (School of Information Technology, Deakin University, Geelong, Australia).

By territory, 4 authors are of European origin (3 Spanish: Muñoz, Santana, and Stores; and 1 British: Barnaghi); 3 are of Asian origin (Al-Turjman, Park, and Guizani), 2 are of American origin (Choo and Kantarci) and 1 is of Australian origin (Zaslavsky). In this line, by subject area, all the authors of this ranking classify their articles in Computer Science; followed by Engineering with 5 authors; and Mathematics and Energy with 1 author each.

In other words, the main thematic areas (Computer Science and Engineering) associated with the most prolific authors' articles have been identified. These areas reflect the interests of this scientific field, which has implications both in technology and processes, as well as in innovation and ubiquity, all related to an infrastructure complex with the aim of improving the lives of city dwellers $[138,139]$.

Moreover, among the 10 most productive authors on this topic in the 2011-2019 period, the keywords most used by them, not counting "Internet of Things" or "Smart City", are mainly linked, in order, to cluster 6 (Blockchain, Network Architecture, Cloud Computing, and Digital Storage); cluster 5 (Internet, Electronic Commerce, and Experimentation); cluster 3 (Waste Management, Data Mining, Network Security, and Waste Disposal); cluster 2 (Energy Utilization, 5G Mobile Communication 
Systems, Extensive Simulations, and Power Management (telecommunication)); cluster 1 (Data Acquisition, Data Analytics, Semantics, Crowdsensing, and Information and Communication Technologies); and cluster 4 (Testbed).

On the other hand, the top 10 authors of this topic associate their articles, mainly, with research lines that analyze cloud computing, that is, the paradigm that offers computer services through the Internet [39]; and automation, which refers to the application of machines or automatic procedures in carrying out a process or in an industry $[44,136]$.

Figure 5 displays the cooperation map between the authors, based on co-authorship analysis, who have published globally on smart cities based on IoT technology applications. The color of each cluster is related with the group of authors in the publication of articles, while the diameter of the circle indicates the number of articles by the author. The authors in this research topic are associated into 7 groups. In this sense, it is noteworthy that cluster 1, the most numerous, is mostly made up of authors of Chinese origin, and it is in a central position, confirming its potential for research and cooperation among its members. Likewise, component 2 describes the cooperation of the American authors who also confirm their potential researcher at a global level. This cluster is positioned laterally with a certain distance from component 1 , which mainly includes authorship of Chinese origin. On the other hand, it is observed that cluster 5, predominantly of Spanish collaboration, is located laterally and is somewhat detached from the rest of the clusters.

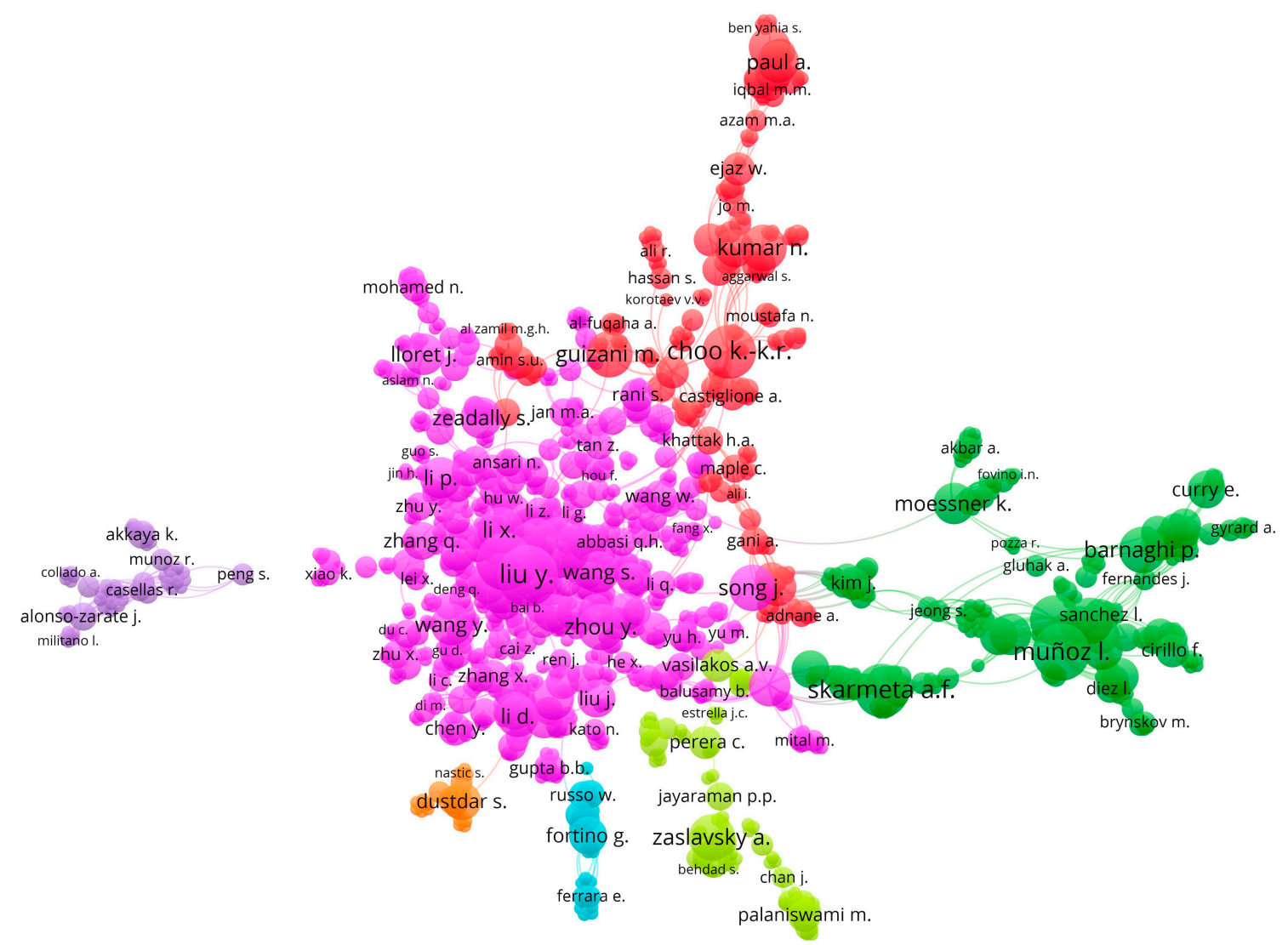

Figure 5. Authors network based on co-authorship method (2011-2019).

Table 12 presents the leading authors by number of articles and the main collaborating authors of each of the 7 clusters formed. 
Table 12. Clusters of authors (2011-2019).

\begin{tabular}{|c|c|c|c|c|c|c|c|}
\hline Cluster & $\begin{array}{l}\text { Cluster Color } \\
\text { (See in Figure 5) }\end{array}$ & $\%$ & Authors & Articles & Links & TLS & Citations \\
\hline \multirow{5}{*}{1} & Pink & $54.92 \%$ & Liu Y. $\left({ }^{*}\right)$ & 11 & 49 & 53 & 189 \\
\hline & & & Zhang Y. & 11 & 41 & 46 & 139 \\
\hline & & & Liu X. & 10 & 36 & 40 & 147 \\
\hline & & & Wang X. & 8 & 29 & 29 & 88 \\
\hline & & & Zhou Y. & 7 & 27 & 30 & 119 \\
\hline \multirow{5}{*}{2} & Green & $15.89 \%$ & Muñoz L. $\left.{ }^{*}\right)$ & 10 & 31 & 57 & 681 \\
\hline & & & Skarmeta A.F. & 9 & 25 & 34 & 235 \\
\hline & & & Santana J.R. & 8 & 42 & 68 & 420 \\
\hline & & & Sotres P. & 7 & 25 & 49 & 412 \\
\hline & & & Barnaghi P. & 7 & 23 & 36 & 164 \\
\hline \multirow{5}{*}{3} & Red & $15.66 \%$ & Choo K.-K.R. $\left.{ }^{*}\right)$ & 9 & 33 & 36 & 242 \\
\hline & & & Kumar N. & 7 & 21 & 29 & 165 \\
\hline & & & Guizani M. & 7 & 25 & 26 & 164 \\
\hline & & & Paul A. & 6 & 11 & 22 & 485 \\
\hline & & & Rathore M.M. & 6 & 15 & 24 & 485 \\
\hline \multirow{5}{*}{4} & Yellow & $5.90 \%$ & Zaslavsky A. $\left({ }^{*}\right)$ & 7 & 25 & 31 & 627 \\
\hline & & & Perera C. & 4 & 15 & 15 & 861 \\
\hline & & & Palaniswami M. & 4 & 14 & 18 & 636 \\
\hline & & & Vasilakos A.V. & 4 & 19 & 19 & 296 \\
\hline & & & Anagnostopoulos $\mathrm{T}$. & 4 & 16 & 21 & 116 \\
\hline \multirow{5}{*}{5} & Violet & $4.09 \%$ & Alonso-Záate J. $\left(^{*}\right)$ & 3 & 25 & 25 & 100 \\
\hline & & & Akkaya K. & 3 & 8 & 8 & 23 \\
\hline & & & Casellas R. & 2 & 30 & 32 & 76 \\
\hline & & & Verikoukis C. & 2 & 30 & 32 & 76 \\
\hline & & & Vilalta R. & 2 & 30 & 32 & 76 \\
\hline \multirow{5}{*}{6} & Cyan & $1.97 \%$ & Fortino G. $\left({ }^{*}\right)$ & 5 & 16 & 23 & 405 \\
\hline & & & Russo W. & 3 & 7 & 14 & 100 \\
\hline & & & Savaglio C. & 3 & 7 & 14 & 100 \\
\hline & & & Pianini D. & 3 & 8 & 14 & 78 \\
\hline & & & Viroli M. & 3 & 8 & 14 & 78 \\
\hline \multirow{5}{*}{7} & Orange & $1.5 \%$ & Dustdar S. $\left(^{*}\right)$ & 5 & 13 & 19 & 95 \\
\hline & & & Vögler M. & 4 & 11 & 15 & 88 \\
\hline & & & Inzinger C. & 3 & 4 & 9 & 76 \\
\hline & & & Schleicher J.M. & 3 & 4 & 9 & 76 \\
\hline & & & Truong H.-L. & 2 & 13 & 13 & 22 \\
\hline
\end{tabular}

$\%$ : percentage of total authors; $\left({ }^{*}\right)$ leading author; TLS: Total Link Strength.

The network of authors denotes the potential, fundamentally, of authors of Chinese, North American, and Spanish origin. This result is confirmed by the development of scientific activity in these countries. In this sense, the participation of public and private entities promote production for the purposes of these programs $[140,141]$.

\subsubsection{Research Institutions}

The 1232 articles selected in smart cities based on IoT technology applications research have been written in 2680 international affiliations. Table 13 displays the 10 most prolific research institutions in this topic. This ranking highlights that $50 \%$ are of European origin (University of Surrey, Universidad de Cantabria, Universidad de Murcia, Alma Mater Studiorum Università di Bologna, and Universitat Politècnica de Catalunya) and 50\% are of Asian origin (King Saud University, University of Electronic Science and Technology of China, COMSATS University Islamabad, K L Deemed to be University, 
and Kyungpook National University). Moreover, all these research institutions classify their published articles into the Computer Science and Engineering categories.

Table 13. Top 10 research institutions and main keywords (2011-2019).

\begin{tabular}{|c|c|c|c|c|c|c|c|c|c|}
\hline Research Institution & A & Country & $\begin{array}{c}\text { Subject } \\
\text { Area }\end{array}$ & $\mathbf{h}^{*}$ & $1 A^{*}$ & LA * & Keyword 1 & Keyword 2 & Keyword 3 \\
\hline King Saud University & 20 & $\begin{array}{l}\text { Saudi } \\
\text { Arabia }\end{array}$ & CS-EN & 11 & 2013 & 2019 & Big Data & $\begin{array}{c}\text { Deep } \\
\text { Learning }\end{array}$ & Health Care \\
\hline University of Surrey & 18 & UK & CS-EN & 9 & 2012 & 2019 & Data Mining & $\begin{array}{l}\text { Information } \\
\text { Management }\end{array}$ & Internet \\
\hline $\begin{array}{c}\text { University of } \\
\text { Electronic Science and } \\
\text { Technology of China }\end{array}$ & 17 & China & CS-EN & 8 & 2016 & 2019 & $\begin{array}{l}\text { 5G Mobile } \\
\text { Communication } \\
\text { System }\end{array}$ & Cryptography & $\begin{array}{c}\text { Data } \\
\text { Communication } \\
\text { System }\end{array}$ \\
\hline $\begin{array}{l}\text { Universidad de } \\
\text { Cantabria }\end{array}$ & 17 & Spain & CS-EN & 10 & 2011 & 2019 & Internet & $\begin{array}{l}\text { Electronic } \\
\text { Commerce }\end{array}$ & Co-creation \\
\hline Universidad de Murcia & 16 & Spain & CS-EN & 10 & 2013 & 2019 & Internet & $\begin{array}{l}\text { Internet } \\
\text { Protocol }\end{array}$ & Energy Efficiency \\
\hline $\begin{array}{c}\text { Alma Mater } \\
\text { Studiorum Università } \\
\text { di Bologna }\end{array}$ & 15 & Italy & CS-EN & 9 & 2013 & 2019 & $\begin{array}{l}\text { Aggregate } \\
\text { Computing }\end{array}$ & $\begin{array}{l}\text { Distributed } \\
\text { Computer } \\
\text { System }\end{array}$ & Simulation \\
\hline $\begin{array}{l}\text { COMSATS University } \\
\text { Islamabad }\end{array}$ & 15 & Pakistan & CS-EN & 8 & 2017 & 2019 & Automation & $\begin{array}{l}\text { Intelligent } \\
\text { Building }\end{array}$ & Energy Efficiency \\
\hline $\begin{array}{l}\text { Universitat Politècnica } \\
\text { de Catalunya }\end{array}$ & 13 & Spain & EN-CS & 8 & 2015 & 2019 & Automation & $\begin{array}{l}\text { Distributed } \\
\text { Computer } \\
\text { System }\end{array}$ & Energy \\
\hline $\begin{array}{l}\text { K L Deemed to be } \\
\text { University }\end{array}$ & 13 & India & EN-CS & 2 & 2016 & 2019 & Security & $\begin{array}{l}\text { Wireless } \\
\text { Sensor } \\
\text { Network }\end{array}$ & Air Pollution \\
\hline $\begin{array}{c}\text { Kyungpook National } \\
\text { University }\end{array}$ & 12 & $\begin{array}{l}\text { South } \\
\text { Korea }\end{array}$ & CS-EN & 8 & 2016 & 2019 & Big Data & Automation & $\begin{array}{l}\text { Intelligent } \\
\text { Building }\end{array}$ \\
\hline
\end{tabular}

A: number of articles; EN: Engineering; CS: Computer Science; h: h-index or Hirsch index; 1A: first article; LA: last article; $(*)$ in this research topic.

Regarding the subject areas, all the research institutions classify the articles produced in Computer Science and Engineering, just as it happens with all scientific production.

On the other hand, Table 13 also shows the main keywords associated with the articles published by the top 10 institutions in this research field. Among the most outstanding research institutions, the presence of the Vellore Institute of Technology (India) and the Chinese Academy of Sciences (China), which are made up of several organizations, are observed. Even though their contributions do not make a significant difference and occupy positions 7 and 8, respectively, the decision has been made not to include them in this ranking. In this ranking, the search keywords (Internet of Things, Smart City) have been omitted, since they occupied the first two positions in all research institutions. As for the main keywords linked to the top 10 research institutions and that define the thematic axes that they develop, they stand out: cluster 1 (Big Data, Distributed Computer System, Health Care, Information Management, Air Pollution); cluster 2 (5G Mobile Communication System, Data Communication Systems, Energy Efficiency, Simulation, Security, Wireless Sensor Network); cluster 3 (Data Mining, Deep Learning, Internet Protocol); cluster 5 (Electronic Commerce, Energy, Internet); and cluster 7 (Automation, Intelligent Building). In other words, it is observed from the research lines of these authors that the topics developed in their articles reach a wide range of aspects; although it also highlights that the thematic axis related to clusters 4 and 6 are not as well developed among these authors.

The process of digital transformation in the IoT in smart cities has a more collective than individual impact on research. Institutions play a key role in the implementation of projects that promote initiatives around different multidisciplinary objectives. This assumes that scientific activity is not concentrated in a few institutions, but rather that there is a wide variety that affects the research focus, as evidenced by the different key terms of the top 10 institutions [142]. 
Figure 6 shows the network of research institutions based on the co-authorship analysis. The VOSviewer software tool associates them into 5 groups. The co-authorship analysis of the research institutions infer that a greater number of actors involved in this topic will have an impact on accelerating the adoption of technology and generating a greater scientific impact. Thus, the multidisciplinary approach of this research field is linked to that of the variety of research institutions involved [143].

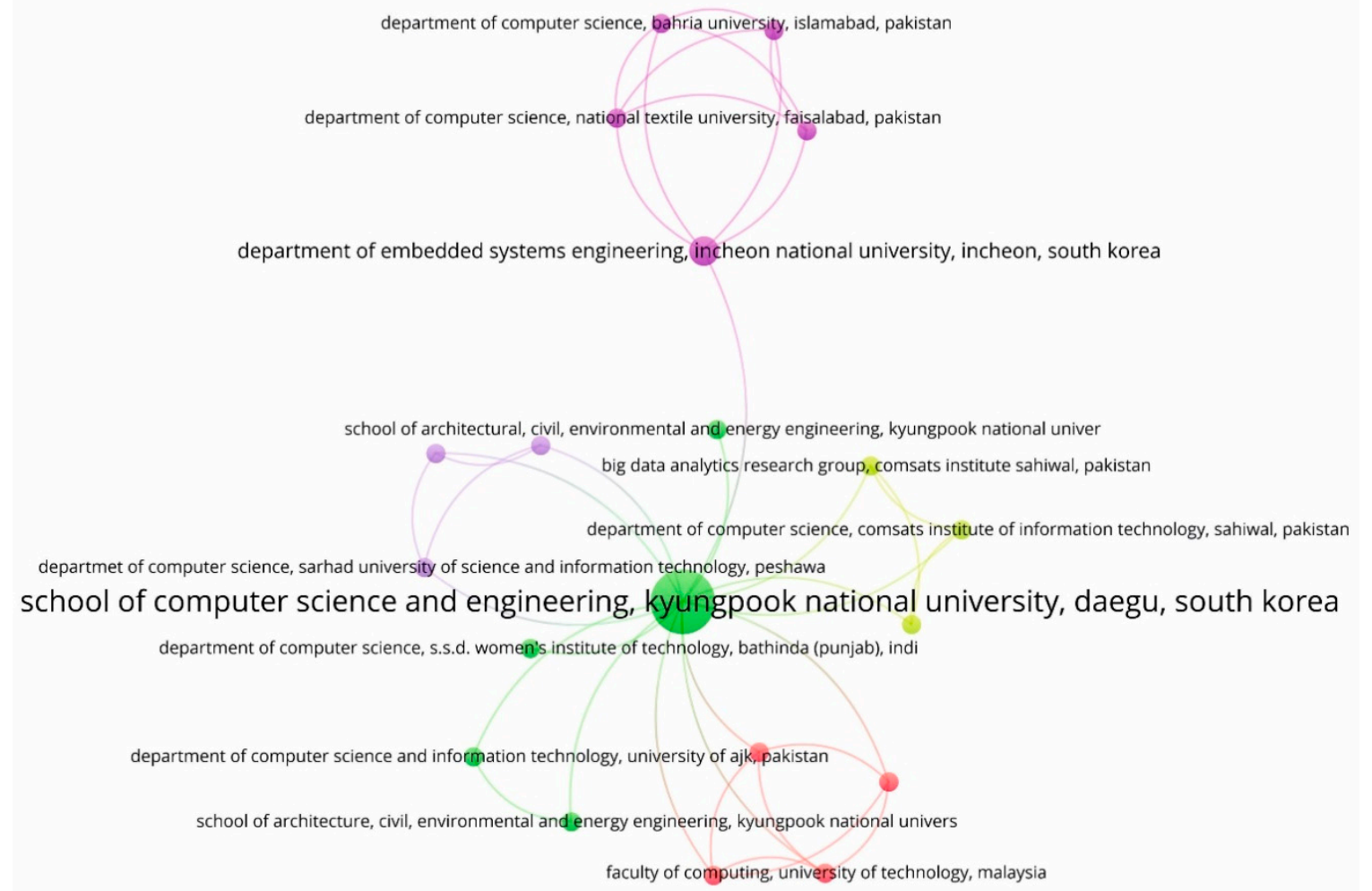

Figure 6. Research Institutions network based on the co-authorship method (2011-2019).

Table 14 presents the leading research institutions by number of articles and the main collaborating authors of each of the 5 clusters formed.

Table 14. Clusters of authors (2011-2019).

\begin{tabular}{|c|c|c|c|c|c|c|c|}
\hline $\begin{array}{l}\text { Cluster } \\
\text { Number }\end{array}$ & $\begin{array}{l}\text { Cluster Color } \\
\text { (See in Figure 6) }\end{array}$ & $\%$ & Research Institution & $\begin{array}{l}\text { Region, } \\
\text { Country }\end{array}$ & $\mathbf{A}$ & L & C \\
\hline \multirow{5}{*}{1} & Pink & $25 \%$ & $\begin{array}{l}\text { Department of Embedded } \\
\text { Systems Engineering (Incheon } \\
\text { National University) }\end{array}$ & $\begin{array}{l}\text { Incheon, } \\
\text { South Korea }\end{array}$ & 2 & 5 & 41 \\
\hline & & & $\begin{array}{l}\text { Department of Computer Science } \\
\text { (Bahria University) }\end{array}$ & $\begin{array}{l}\text { Islamabad, } \\
\text { Pakistan }\end{array}$ & 1 & 4 & 2 \\
\hline & & & $\begin{array}{l}\text { Department of Computer Science } \\
\text { (National Textile University }\end{array}$ & $\begin{array}{l}\text { Faisalabad, } \\
\text { Pakistan }\end{array}$ & 1 & 4 & 2 \\
\hline & & & $\begin{array}{l}\text { Department of Computer } \\
\text { Science, University of } \\
\text { Engineering and Technology }\end{array}$ & $\begin{array}{l}\text { Taxila, } \\
\text { Pakistan }\end{array}$ & 1 & 4 & 2 \\
\hline & & & $\begin{array}{l}\text { School of Electronic Engineering } \\
\text { (Xidian University) }\end{array}$ & $\begin{array}{l}\text { Shaanxi, } \\
\text { China }\end{array}$ & 1 & 4 & 2 \\
\hline
\end{tabular}


Table 14. Cont.

\begin{tabular}{|c|c|c|c|c|c|c|c|}
\hline $\begin{array}{l}\text { Cluster } \\
\text { Number }\end{array}$ & $\begin{array}{l}\text { Cluster Color } \\
\text { (See in Figure 6) }\end{array}$ & $\%$ & Research Institution & $\begin{array}{l}\text { Region, } \\
\text { Country }\end{array}$ & A & $\mathbf{L}$ & $\mathrm{C}$ \\
\hline \multirow{4}{*}{2} & Green & $25 \%$ & $\begin{array}{l}\text { School of Computer Science and } \\
\text { Engineering, Kyungpook } \\
\text { National University }\end{array}$ & $\begin{array}{c}\text { Daegu, } \\
\text { South Korea }\end{array}$ & 7 & 15 & 120 \\
\hline & & & $\begin{array}{c}\text { Department of Computer Science } \\
\text { and Information Technology, } \\
\text { University of Ajk }\end{array}$ & $\begin{array}{l}\text { Cachemira } \\
\text { Azad, } \\
\text { Pakistan }\end{array}$ & 1 & 2 & 38 \\
\hline & & & $\begin{array}{l}\text { Department of Computer } \\
\text { Science, S.S.D. Women's Institute } \\
\text { of Technology }\end{array}$ & $\begin{array}{c}\text { Bathinda } \\
\text { (Punjab), India }\end{array}$ & 1 & 1 & 14 \\
\hline & & & $\begin{array}{l}\text { School of Architecture, Civil, } \\
\text { Environmental and Energy } \\
\text { Engineering, Kyungpook } \\
\text { National University }\end{array}$ & $\begin{array}{l}\text { Daegu, } \\
\text { South Korea }\end{array}$ & 1 & 2 & 42 \\
\hline \multirow{4}{*}{3} & Red & $20 \%$ & $\begin{array}{l}\text { Department of Computer } \\
\text { Science, University of Peshawar }\end{array}$ & $\begin{array}{l}\text { Peshawar, } \\
\text { Pakistan }\end{array}$ & 1 & 4 & 2 \\
\hline & & & $\begin{array}{l}\text { Department of Control and } \\
\text { Computer Engineering (Dauin) }\end{array}$ & Torino, Italy & 1 & 4 & 2 \\
\hline & & & $\begin{array}{l}\text { Faculty of Computing, } \\
\text { University of Technology }\end{array}$ & $\begin{array}{l}\text { Skudai, } \\
\text { Malaysia }\end{array}$ & 1 & 4 & 2 \\
\hline & & & $\begin{array}{c}\text { School of Computing, Universiti } \\
\text { Utara Malaysia (UUM) }\end{array}$ & $\begin{array}{l}\text { Kedah, } \\
\text { Malaysia }\end{array}$ & 1 & 4 & 2 \\
\hline \multirow{3}{*}{4} & Yellow & $15 \%$ & $\begin{array}{c}\text { Big Data Analytics Research } \\
\text { Group, Comsats Institute } \\
\text { Sahiwal }\end{array}$ & $\begin{array}{l}\text { Sahiwal, } \\
\text { Pakistan }\end{array}$ & 1 & 3 & 8 \\
\hline & & & $\begin{array}{c}\text { Department of Computer } \\
\text { Science, Comsats Institute of } \\
\text { Information Technology (Ciit) }\end{array}$ & $\begin{array}{l}\text { Vehari, } \\
\text { Pakistan }\end{array}$ & 1 & 3 & 8 \\
\hline & & & $\begin{array}{l}\text { Department of Computer } \\
\text { Science, Comsats Institute of } \\
\text { Information Technology }\end{array}$ & $\begin{array}{l}\text { Sahiwal, } \\
\text { Pakistan }\end{array}$ & 1 & 3 & 8 \\
\hline \multirow{3}{*}{5} & Violet & $15 \%$ & $\begin{array}{c}\text { Department of Computer } \\
\text { Software Engineering, National } \\
\text { University of Sciences } \\
\text { and Technology }\end{array}$ & $\begin{array}{l}\text { Islamabad, } \\
\text { Pakistan }\end{array}$ & 1 & 3 & 13 \\
\hline & & & $\begin{array}{l}\text { Department of Information } \\
\text { Communications Engineering, } \\
\text { Hankuk University of } \\
\text { Foreign Studies }\end{array}$ & $\begin{array}{l}\text { Seoul, } \\
\text { South Korea }\end{array}$ & 1 & 3 & 13 \\
\hline & & & $\begin{array}{l}\text { Departmet of Computer Science, } \\
\text { Sarhad University of Science and } \\
\text { Information Technology }\end{array}$ & $\begin{array}{l}\text { Peshawar, } \\
\text { Pakistan }\end{array}$ & 1 & 3 & 13 \\
\hline
\end{tabular}

$\%$ : percentage of total research institutions; $\left({ }^{*}\right)$ leading institution; A: articles; L: Links; C: citations.

\subsubsection{Countries}

In this research topic, the 1232 articles were written in 93 different countries. Table 15 shows the top 10 countries in this research field. The country with the most articles is China (articles: 216, percentage of total: $17.53 \%)$, followed by the United States (201, 16.31\%), India (195, 15.83\%), Spain $(137,11.12 \%)$, Italy $(108,8.77 \%)$, the United Kingdom (104, 8.44\%), South Korea (81, 6.57\%), Australia (62, 5.03\%), Canada (55, 4.46\%), and Pakistan (53, 4.30\%). 
Table 15. Top 10 Countries and main keywords (2011-2019).

\begin{tabular}{cccccccccc}
\hline Country & A & $\%$ & Subject Area & $\mathbf{h}^{*}$ & $\mathbf{1 A}^{*}$ & $\mathbf{L A} *$ & Keyword 1 & Keyword 2 & Keyword 3 \\
\hline China & 216 & 17.53 & CS-EN & 35 & 2011 & 2019 & Big Data & Network Security & Automation \\
USA & 201 & 16.31 & CS-EN & 37 & 2013 & 2019 & Big Data & Automation & Wireless Sensor Network \\
India & 195 & 15.83 & EN-CS & 20 & 2015 & 2019 & Wireless Sensor Network & Cloud Computing & Big Data \\
Spain & 137 & 11.12 & CS-EN & 26 & 2011 & 2019 & Internet & Energy Utilization & Wireless Sensor Network \\
Italy & 108 & 8.77 & CS-EN & 27 & 2012 & 2019 & Internet & Big Data & Wireless Sensor Network \\
UK & 104 & 8.44 & CS-EN & 29 & 2012 & 2019 & Internet & Big Data & Information Management \\
South Korea & 81 & 6.57 & CS-EN & 18 & 2013 & 2019 & Network Security & Automation & Big Data \\
Australia & 62 & 5.03 & CS-EN & 19 & 2014 & 2019 & Internet & Big Data & Cloud Computing \\
Canada & 55 & 4.46 & CS-EN & 16 & 2013 & 2019 & Automation & Big Data & Energy Efficiency \\
Pakistan & 53 & 4.30 & CS-EN & 14 & 2016 & 2019 & Big Data & Automation & Intelligent Building
\end{tabular}

A: number of articles; \%: percentage of total articles published; CS: Computer Science; EN: Engineering; h: h-index or Hirsch index; 1A: first article; LA: last article; $\left(^{*}\right)$ in this research topic.

The articles published by the top 10 countries in the research on IoT technology applications-based smart cities are classified mainly in the same subject areas that make up the majority of the scientific production examined (see Figure 3), that is, Sciences of the Computing and Engineering.

Furthermore, Table 15 also presents the 3 main keywords for the most productive countries in this research topic. The main terms used by the top 10 countries in this thematic area in their articles are associated with six of the identified thematic axes, except for the one that develops the line on "wireless telecommunication systems". Therefore, each cluster is represented by a set of terms that identify the topics mainly dealt with by these countries during the period 2011-2019. Hence, cluster 1 (Big Data, Information Management); cluster 2 (Energy Utilization, Wireless Sensor Network); cluster 3 (Energy Efficiency, Network Security); cluster 5 (Internet); cluster 6 (Cloud Computing); and cluster 7 (Automation, Intelligent Building).

The multidisciplinary approach of this research topic is related to the variety of countries and continents involved. Thereby, in the same way that it happens with the authors and research institutions, in the countries, as observed in the reviewed literature and in the keywords of the top 10 countries, there is also a multidisciplinary research $[144,145]$.

Figure 7 shows the choropleth map of the countries that contribute to the development of smart cities based on IoT technology applications research. The color range of the blue color has been used to represent the number of articles published on this topic. This map allows visualizing the level of variability of the research at a global level.

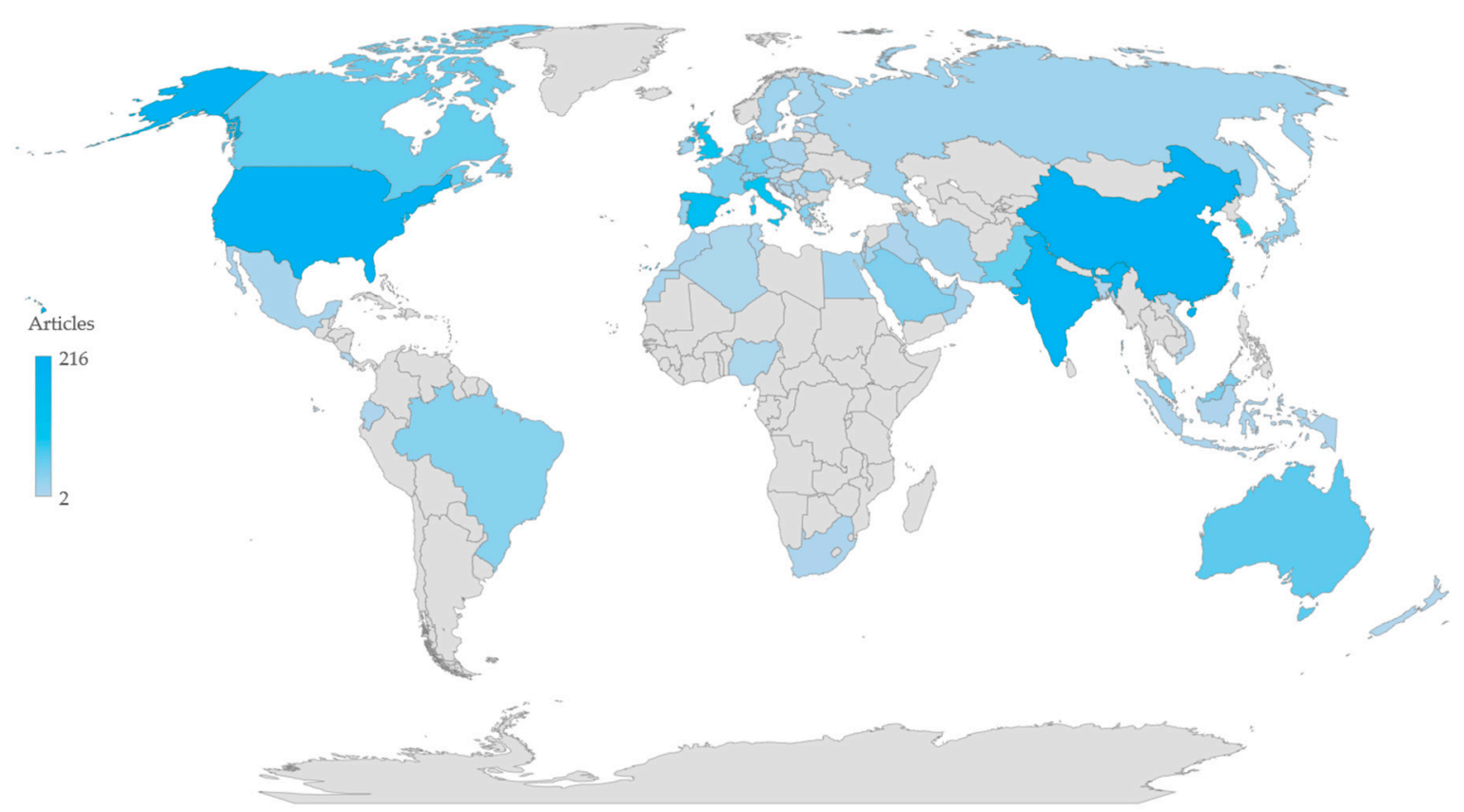

Figure 7. Scientific production by countries (2011-2019). 
Despite the fact that the United States, China, and India, as benchmarks for North America and Asia, bear the weight of research on smart cities based on IoT technology applications globally, the map also shows that Europe, with Spain, Italy, and the United Kingdom, also join this leadership. Australia, on the other hand, is also giving Oceania a voice in this research, and to a lesser extent, both Latin America and Africa are contributing to the more social approach to this topic [146].

Figure 8 shows a collaboration network between the main countries based on the co-authorship analysis. Different colors represent the different clusters formed by the groups of countries, while the diameter of the circle varies depending on the number of articles published by each country. The VOSviewer software has grouped them into 6 components.

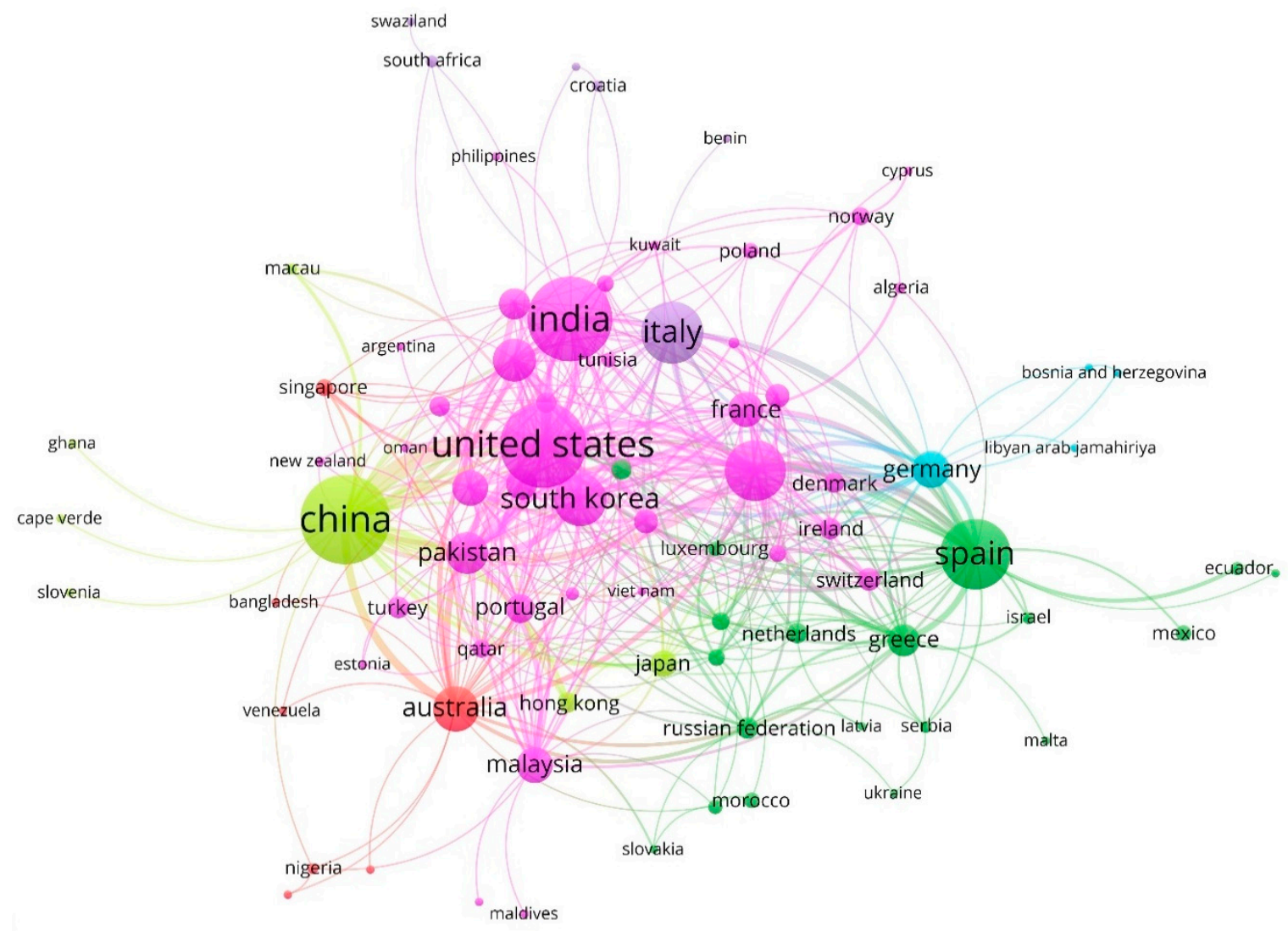

Figure 8. Countries network based on the co-authorship method (2011-2019).

Table 16 presents the leading countries by number of articles and the main collaborating countries of each of the 6 clusters formed.

Globally, the co-authorship analysis of the countries indicates that a greater number of participants will have an impact on accelerating research on the adoption of new technologies in smart cities. The centrality of the United States indicates the strength of its research activity and cooperation in its contributions at the international level. Likewise, China stands out in the development of this research field. The association in different clusters adds value to the international sound of this topic and promotes the participation and contributions of any country [147]. 
Table 16. Clusters of countries (2011-2019).

\begin{tabular}{|c|c|c|c|c|c|c|c|}
\hline Cluster & $\begin{array}{c}\text { Cluster Color } \\
\text { (See in Figure 8) }\end{array}$ & $\%$ & Country & Articles & Links & TLS & Citations \\
\hline \multirow{5}{*}{1} & Pink & $47.56 \%$ & United States $(*)$ & 201 & 40 & 213 & 5441 \\
\hline & & & India & 195 & 33 & 77 & 1350 \\
\hline & & & United Kingdom & 104 & 38 & 165 & 3312 \\
\hline & & & South Korea & 81 & 26 & 89 & 1671 \\
\hline & & & Canada & 55 & 29 & 75 & 935 \\
\hline \multirow{5}{*}{2} & Green & $23.17 \%$ & Spain $(*)$ & 137 & 33 & 127 & 5073 \\
\hline & & & Greece & 32 & 24 & 66 & 1213 \\
\hline & & & Russian & 15 & 16 & 30 & 500 \\
\hline & & & Netherlands & 13 & 12 & 15 & 108 \\
\hline & & & Belgium & 11 & 17 & 23 & 365 \\
\hline \multirow{5}{*}{3} & Red & $8.54 \%$ & Australia (*) & 62 & 29 & 85 & 2287 \\
\hline & & & Singapore & 10 & 8 & 15 & 166 \\
\hline & & & Nigeria & 4 & 4 & 4 & 287 \\
\hline & & & Bangladesh & 2 & 3 & 3 & 13 \\
\hline & & & Botswana & 1 & 2 & 2 & 10 \\
\hline \multirow{5}{*}{4} & Yellow & $8.54 \%$ & China $(*)$ & 218 & 39 & 202 & 5002 \\
\hline & & & Japan & 22 & 9 & 18 & 310 \\
\hline & & & Hong Kong & 14 & 5 & 17 & 178 \\
\hline & & & Macau & 4 & 3 & 8 & 728 \\
\hline & & & Slovenia & 2 & 1 & 1 & 25 \\
\hline \multirow{5}{*}{5} & Violet & $7.32 \%$ & Italy $(*)$ & 108 & 27 & 87 & 5856 \\
\hline & & & South Africa & 5 & 4 & 4 & 73 \\
\hline & & & Croatia & 4 & 3 & 3 & 21 \\
\hline & & & Benin & 1 & 1 & 1 & 4 \\
\hline & & & Chile & 1 & 2 & 2 & 9 \\
\hline \multirow{4}{*}{6} & Cyan & $4.88 \%$ & Germany (*) & 41 & 26 & 55 & 1136 \\
\hline & & & $\begin{array}{l}\text { Bosnia and } \\
\text { Herzegovina }\end{array}$ & 2 & 2 & 2 & 38 \\
\hline & & & Montenegro & 2 & 3 & 3 & 39 \\
\hline & & & Libyan & 1 & 1 & 1 & 0 \\
\hline
\end{tabular}

\%: percentage of total countries; (*) leading country; TLS: Total Link Strength.

\subsection{Future Research Directions}

Section 4.5 presents the evolution that keywords have followed in the research in smart cities based on IoT technology applications during the period examined. Hence, the pioneering terms associated with this research are identified, which have been incorporated from the increase in published articles. For this reason, Figure 9 shows the evolution and maturity of each keyword community, since it differentiates the period in which they have been analyzed and associated with the articles examined. In this way, it is verified that there has been a progress in terminology in smart cities based on IoT technology applications research.

In this evolution of keywords associated with the research topic, Figure 9 shows that the group of pioneering keywords was incorporated and has allowed the study of smart cities based on IoT technology applications to be formed; this group includes smartphones, web services, augmented reality, network, and cloud computing technologies. In this first stage, the research has been devoted in a transversal way to the analysis and study of technologies that respond to the development and use of artificial intelligence and data analytics, connectivity, security, and well-being [148]. Next, the research focuses on studying the economic, environmental, and social challenges. The analysis of innovations worldwide allows collective participation and analyzes the key issues of Internet regulation and identifies solutions based on experiences in the previous stage [149]. Later, the research focuses on 
the analysis of smart cities as a process against climate change and the promotion of responsible environmental and health development policies [150].

In this sense, the different subperiods in which the scientific activity of the IoT is being developed in smart cities represent an abundant collection of keywords. This allows checking the variety of study axes in the research activity. Figure 9 visualizes the importance of key terms based on the moment in which they have been associated with this research. Therefore, the oldest have been a reference for the later ones [151,152].

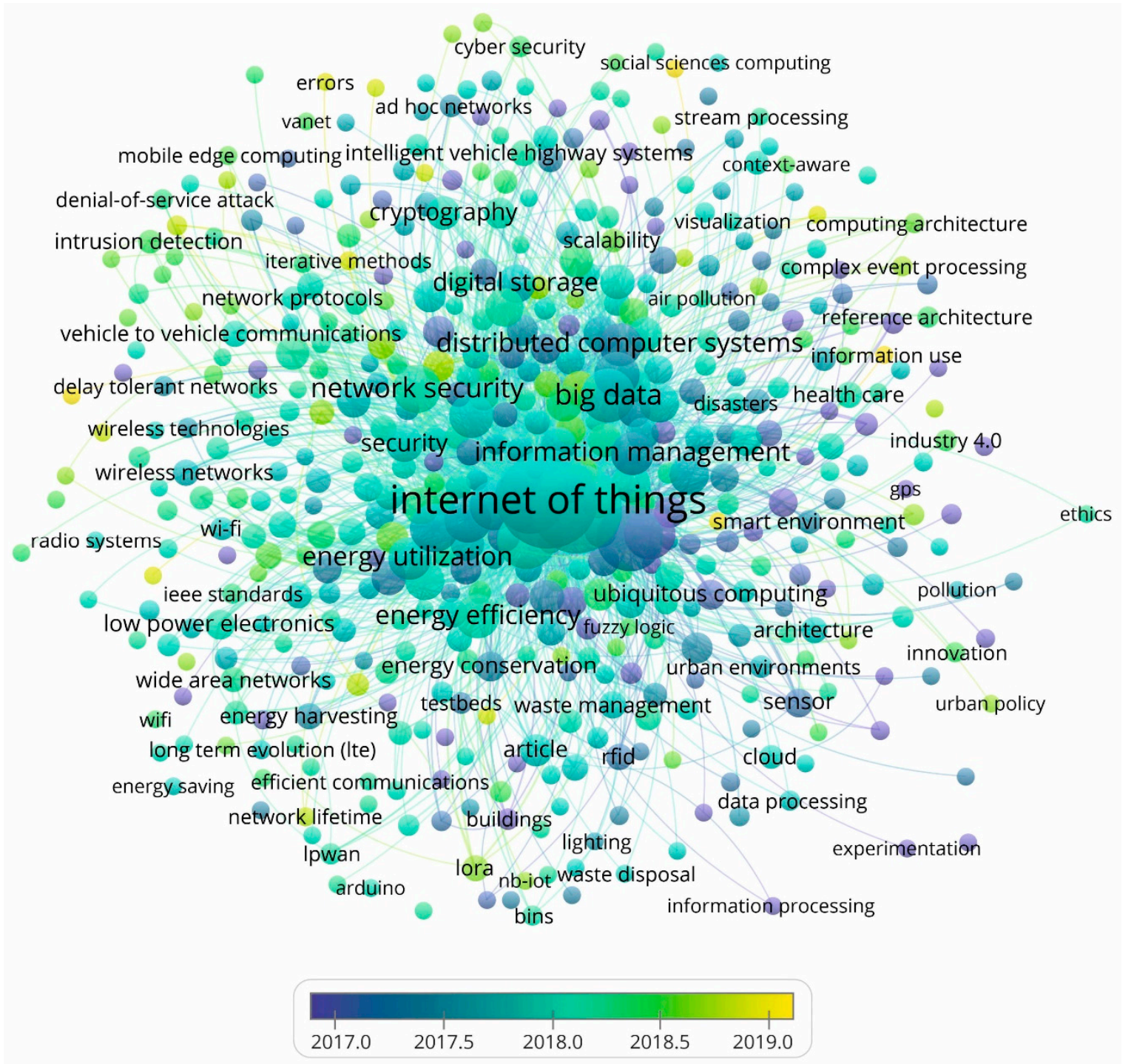

Figure 9. Evolution of keywords network based on co-occurrences (2011-2019).

Global research in smart cities based on IoT technology applications continues to advance and evolve. In this way, other concepts are being incorporated that make up new points of view and strategies, which propose new lines of research. The set of the last terms associated with this research has been identified, so that it has allowed them to be associated with new directions in the research. These are related to the development of topics covered and even to the emergence of new approaches. Hence, seven future research directions and various topics associated with these have been identified.

The grouping analysis carried out consisted of decomposing the units of analysis into groups of similar elements and determining the newest terms. The keywords obtained would be assimilable to future thematic lines in this field of research. This procedure constitutes an effective method to discover emerging trends and themes in a scientific discipline. Hence, Table 17 shows the new lines of 
research identified by the number of links and the total link strength. In addition, a description of each of the future research directions detected is added.

Table 17. Future research lines.

\begin{tabular}{|c|c|c|c|}
\hline Research Line & Links & $\begin{array}{l}\text { Total Link } \\
\text { Strength }\end{array}$ & Description \\
\hline Energy Storage & 67 & 71 & $\begin{array}{c}\text { Efficient energy storage as an essential support for the energy } \\
\text { transition and key to a decarbonized future. This allows } \\
\text { flexibility in the production of renewable energy and } \\
\text { guarantees its integration into the system. }\end{array}$ \\
\hline $\begin{array}{l}\text { Environmental } \\
\text { Temperature }\end{array}$ & 48 & 48 & $\begin{array}{l}\text { Development of measurement, instruments, and applications } \\
\text { of sensors for environmental and urban temperature. } \\
\text { Establish an intelligence guide to ambient temperature in the } \\
\text { IoT environment. }\end{array}$ \\
\hline $\begin{array}{l}\text { Geographic } \\
\text { Distribution }\end{array}$ & 48 & 48 & $\begin{array}{l}\text { Use of remote sensors in the analysis of landscape } \\
\text { fragmentation to monitor the patterns involved in } \\
\text { fragmentation processes and thus avoid the loss of ecosystems } \\
\text { and biodiversity. }\end{array}$ \\
\hline $\begin{array}{l}\text { Intentional } \\
\text { Contaminations }\end{array}$ & 40 & 40 & $\begin{array}{l}\text { Increased research on pollution sensors that measure } \\
\text { environmental variables, such as the concentration of } \mathrm{CO}_{2} \text { and } \\
\text { particles in suspension, in addition to generating urban } \\
\text { pollution maps by region. }\end{array}$ \\
\hline $\begin{array}{l}\text { Remote Health } \\
\text { Monitoring }\end{array}$ & 32 & 32 & $\begin{array}{l}\text { Remote patient monitoring technology that allows patient } \\
\text { observation outside of conventional clinical settings. This will } \\
\text { mean access to care and lower costs of medical care. }\end{array}$ \\
\hline End Users & 29 & 30 & $\begin{array}{l}\text { Training tools for end users of information systems. Study of } \\
\text { the user experience in the positive evolution of the smart city } \\
\text { based on IoT, from the comfort, security, and control associated } \\
\text { with connectivity. Analysis of the perception of the benefits of } \\
\text { the IoT by the end user, for example, in energy savings in the } \\
\text { home or car or in a more efficient use of daily activities. }\end{array}$ \\
\hline $\begin{array}{l}\text { Electronic Crime } \\
\text { Countermeasures }\end{array}$ & 28 & 28 & $\begin{array}{l}\text { Protection against Computer Crime and Information Security, } \\
\text { in addition to regulatory development. }\end{array}$ \\
\hline $\begin{array}{l}\text { Industrial } \\
\text { Internet of Things } \\
\text { (IIoT) }\end{array}$ & 26 & 27 & $\begin{array}{l}\text { Development and extension of the use of the Internet of Things } \\
\text { (IoT) in industrial sectors and applications, such as robotics, } \\
\text { medical devices, and software-defined production processes. }\end{array}$ \\
\hline Flood Control & 27 & 27 & $\begin{array}{l}\text { Design and specifications of flood control systems with IoT } \\
\text { sensors. Real-time control of flood control structures, using } \\
\text { rainfall forecasts, sensor data, and water level and } \\
\text { flow forecasts. }\end{array}$ \\
\hline $\begin{array}{l}\text { Social Internet of } \\
\text { Things (SIoT) }\end{array}$ & 24 & 24 & $\begin{array}{l}\text { Study of how the integration of the principles of social } \\
\text { networks in the IoT generates social and economic impact } \\
\text { among the information consuming society. }\end{array}$ \\
\hline
\end{tabular}

Although the research trends are global, the responses-that is, the materialization of these contributions-are local and varied. This is mainly due to differences in different factors when identifying applications in IoT, such as economic, social, or climatic factors. The progress of the research allows us to recognize various models of smart cities, which are mainly focused on technological aspects, the factor of sustainable development, or digital literacy for a better understanding of digital transformation.

Regarding the initiatives that arise around the development of smart cities based on IoT technology applications, the following stand out. The European Innovation Partnership on Smart Cities and Communities (EIP-SCC), within the European Commission, Regarding the initiatives that arise around the development of smart cities based on applications of IoT technology, the following stand out: 
The European Association of Innovation on Smart Cities and Communities (EIP-SCC), within the European Commission, was developed in the European Union's Research and Innovation Funding Program, Horizon 2020 (H2020). This association combines ICT together with energy and transport management, with the aim of providing innovative responses to environmental challenges, Social and Health Sciences of European Cities [153,154]. Additionally, Alliance for Internet of Things Innovation (AIOTI) is another leading initiative of the European Commission, as a space for the interaction of different IoT actors in Europe, such as research centers, universities, and associations [155,156].

Likewise, there are other means that foster interest in these topics, such as: "Smart Cities World" [157], which provides updated information on the infrastructure necessary to create a smart city; "SmartCity.Press" [158], which transmits updated knowledge, progress, and transformation on smart cities; or "IoT World Today" [159], which provides news and case studies on technologies used in the IoT, in different industries, such as smart cities.

\section{Conclusions}

The aim of this study was to analyze the evolution of scientific production and research trends at a global level, over the last 9 years (2011-2019), on smart cities based on IoT technology applications. To this, a bibliometric analysis of a sample of 1232 articles obtained from the Scopus database has been developed. Fundamentally, the evolution of the number of articles, the subject areas where they are classified, the journals where they are published, the authors, the research institutions, and the most productive countries have been identified. Furthermore, current and future main research lines have been detected.

Scientific production has increased especially in the last triennium (2017-2019), where 1025 articles have been published. These represent $83.20 \%$ of the total on the subject in smart cities based on IoT technology applications, which confirms the relevance at the global level and the impact of this research topic. In the same way, the authors, the research institutions, and the most productive countries also link their articles to these two areas of knowledge. In addition, the most prolific countries in this research topic are China, the United States, India, and Spain.

On the other hand, this study has also identified the most influential areas of knowledge where the publications are classified: Computer Science and Engineering. Although it is a multidisciplinary research field, its link with technology and computing is observed.

In relation to the journals in which IoT articles are published in smart cities, Sensors stands out because since 2013, it has contributed to the field of research with the largest number of articles, and in addition, it classifies them in the thematic areas of Engineering, Physics and Astronomy, Biochemistry, Genetics and Molecular Biology, and Chemistry.

The research lines identified that develop the field of study in smart cities based on IoT technology applications generate contributions on the following: (1) the holistic vision of a smart city; (2) IoT applications; (3) network security solutions; (4) the macroscopic approach to wireless telecommunications systems; (5) the implications of Internet in the development of smart cities; (6) cloud computing and the availability of data centers; and (7) the automation of processes.

Globally, the research in smart cities based on IoT technology applications continues to evolve, so this study has identified new directions in research: (1) Energy Storage; (2) Environmental Temperature; (3) Geographic Distribution; (4) Intentional Contaminations; (5) Remote Health Monitoring; (6) End Users, (7) Electronic Crime Countermeasures; (8) Industrial Internet of Things (IIoT); (9) Flood Control; and (10) Social Internet of Things (SIoT).

This study supposes an analysis of the scientific production and the actors that stimulate the smart cities based on IoT technology applications research, in the period 2011-2019, as well as the identification of the research lines and future research directions. Innovation in this research field has been identified based on the groups of authors, research institutions, countries, and keywords, and also the intensity of the relationships that develop in them. The findings obtained are a complement to knowledge in smart cities based on IoT technology applications and allow establishing the relationship 
between science and technology and favoring the decision-making process. In this way, the individual quality of life of citizens would be benefited, in addition to a collective increase in productivity, since it would be easier for governments to have a better infrastructure at a lower cost to achieve an optimized management of resources.

However, the study has a set of limitations, which have conditioned the results obtained, and these could be considered as the basis for future research articles. Among these limitations, the Scopus database chosen to apply the methodology can be highlighted, as well as the keywords selected to extract the article sample, the study period, the bibliometric methodology used, and even the variables examined. It is also necessary to recognize that using data mining, one could explore large databases and find repetitive patterns that explain the behavior of this data.

Finally, it has been observed that global research in smart cities based on IoT technology applications shows an upward trend, which is derived both from the number of articles and from current and future lines of research. This indicates the interest increasingly accentuated by the academic and scientific community, which is mainly due to the multidisciplinary nature of the subject.

Author Contributions: Conceptualization, methodology, software, formal analysis, resources, data curation and writing—original draft preparation, E.A.-S. and M.-D.G.-Z.; investigation, validation, writing—review and editing, visualization, supervision, project administration, E.A.-S., M.-D.G.-Z., E.L.-M. and E.V.-C.; funding acquisition, E.L.-M. and E.V.-C. All authors have read and agreed to the published version of the manuscript.

Funding: This research received no external funding.

Conflicts of Interest: The authors declare no conflict of interest.

\section{References}

1. Ma, X.; Xue, H. Intelligent Smart City Parking Facility Layout Optimization Based On Intelligent IoT Analysis. Comput. Commun. 2020, 153, 145-151. [CrossRef]

2. Subbulakshmi, K. Smart Recyle Trash Management Systems for Smart City Using IoT. J. Mech. Contin. Math. Sci. 2019, 1. [CrossRef]

3. Bhandari, R.; Swapnil, R.; Nidhi, S.; Dhruvi, D.; Harsh, K. IoT Based Smart City Bin. Int. J. Comput. Appl. 2020, 176, 26-29. [CrossRef]

4. Lee, I. The Internet of Things for Enterprises: An Ecosystem, Architecture, and IoT Service Business Model. Internet Things 2019, 7, 100078. [CrossRef]

5. Samuel, A.; Sipes, C. Making Internet of Things Real. IEEE Internet Things Mag. 2019, 2, 10-12. [CrossRef]

6. Lelli, F. Interoperability of the Time of Industry 4.0 and the Internet of Things. Future Internet 2019, 11, 36. [CrossRef]

7. Olabi, A.G. Circular Economy and Renewable Energy. Energy 2019, 181, 450-454. [CrossRef]

8. Lukin, S.Y. Functions of Public Space in Social Development Processes. Public Adm. Cust. Adm. 2020, 2020, 45-50. [CrossRef]

9. Moazami, A.; Carlucci, S.; Nik, V.M.; Geving, S. Towards Climate Robust Buildings: An Innovative Method for Designing Buildings with Robust Energy Performance under Climate Change. Energy Build. 2019, 202, 109378. [CrossRef]

10. Kummitha, R.K.R.; Crutzen, N. Smart Cities and the Citizen-Driven Internet of Things: A Qualitative Inquiry into an Emerging Smart City. Technol. Forecast. Soc. Chang. 2019, 140, 44-53. [CrossRef]

11. Chandrasekaran, Y.J.; Gunamony, S.L.; Chandran, B.P. Integration of 5G Technologies in Smart Grid Communication-A Short Survey. Int. J. Renew. Energy Dev. 2019, 8, 275-283. [CrossRef]

12. Valtanen, K.; Backman, J.; Yrjola, S. Blockchain-Powered Value Creation in the 5G and Smart Grid Use Cases. IEEE Access 2019, 7, 25690-25707. [CrossRef]

13. Achmad, K.A.; Nugroho, L.E.; Djunaedi, A.; Widyawan, W. Smart City Readiness based on Smart City Council's Readiness Framework. Int. J. Electr. Comput. Eng. (IJECE) 2018, 8, 271-279. [CrossRef]

14. De Waal, M.; Dignum, M. The Citizen in the Smart City. How the Smart City could Transform Citizenship. IT-Inf. Technol. 2017, 59, 263-273. [CrossRef]

15. Eremia, M.; Toma, L.; Sanduleac, M. The Smart City Concept in the 21st Century. Procedia Eng. 2017, 181, 12-19. [CrossRef] 
16. Calzada, I. Problematizing and Politicizing Smart City-Regions: Is Devolution Smart? Territorio 2018, 83, 37-47. [CrossRef]

17. Komninos, N.; Bratsas, C.; Kakderi, C.; Tsarchopoulos, P. Smart City Ontologies: Improving the Effectiveness of Smart City Applications. J. Smart Cities 2016, 1. [CrossRef]

18. Xue, X.; Wang, Q.; Zhang, F. Key Technologies and Application Evolution of Internet of Things. J. Comput. Appl. 2013, 33, 2701-2706. [CrossRef]

19. Gershenfeld, N. Physics and Media. IBM Syst. J. 1996, 35, 575-576. [CrossRef]

20. Gershenfeld, N.; Cohen, D. Internet 0: Interdevice Internetworking-End-to-End Modulation for Embedded Networks. IEEE Circuits Devices Mag. 2006, 22, 48-55. [CrossRef]

21. Hügel, S. From the Garden City to the Smart City. Urban Plan. 2017, 2, 1. [CrossRef]

22. Rachmawati, T.; Pertiwi, P.D. Smart Environment Program, Smart Way to Smart City. Policy Gov. Rev. 2017, 1, 26-36. [CrossRef]

23. Zheng, L. What City Amenities Matter in Attracting Smart People? Pap. Reg. Sci. 2014, 95, 309-327. [CrossRef]

24. Wohlleber, A. N Intercultural Smart City Concept Interkulturelles Smart-City-Konzept. GIS Bus. 2016, 11, 32-36. [CrossRef]

25. Alam, K. A Digital Model for Smart City Using Internet of Things (IoT). Glob. Sci-Tech 2019, 11, 23. [CrossRef]

26. Bader, S.R.; Maleshkova, M.; Lohmann, S. Structuring Reference Architectures for the Industrial Internet of Things. Future Internet 2019, 11, 151. [CrossRef]

27. Dhondse, A.; Singh, S. Blockchain Powered Smart Cities. Commun. Appl. Electron. 2019, 7, 7-11. [CrossRef]

28. Jaloudi, S. Communication Protocols of an Industrial Internet of Things Environment: A Comparative Study. Future Internet 2019, 11, 66. [CrossRef]

29. Mohapatra, H.; Behura, A. IoT Based Smart City with Vehicular Safety Monitoring. Internet Things Cloud Comput. 2019, 7, 54. [CrossRef]

30. Scekic, O.; Nastic, S.; Dustdar, S. Blockchain-Supported Smart City Platform for Social Value Co-Creation and Exchange. IEEE Internet Comput. 2019, 23, 19-28. [CrossRef]

31. Allam, Z.; Newman, P. Redefining the Smart City: Culture, Metabolism and Governance. Smart Cities 2018, 1, 4-25. [CrossRef]

32. Barns, S. Smart Cities and Urban Data Platforms: Designing Interfaces for Smart Governance. City Cult. Soc. 2018, 12, 5-12. [CrossRef]

33. Geetha Pratyusha, M.; Misra, Y.; Anil Kumar, M. IoT Based Reconfigurable Smart City Architecture. Int. J. Eng. Technol. 2018, 7, 175. [CrossRef]

34. Guo, K.; Lu, Y.; Gao, H.; Cao, R. Artificial Intelligence-Based Semantic Internet of Things in a User-Centric Smart City. Sensors 2018, 18, 1341. [CrossRef] [PubMed]

35. Persai, P.; Katiyar, S.K. Development of Information Evaluation System for Smart City Planning Using Geoinformatics Techniques. J. Indian Soc. Remote Sens. 2018, 46, 1881-1891. [CrossRef]

36. Raja, A. A Comprehensive Study on Smart City using BlockChain Technology. Int. J. Comput. Sci. Eng. 2018, 6, 640-643. [CrossRef]

37. Wang, L.; Guo, B.; Yang, Q. Smart City Development with Urban Transfer Learning. Computer 2018, 51, 32-41. [CrossRef]

38. Giannakoulias, A. Cloud Computing Security: Protecting Cloud-Based Smart City Applications. J. Smart Cities 2016, 2, 66-77. [CrossRef]

39. Poslad, S.; Ma, A.; Wang, Z.; Mei, H. Using a Smart City IoT to Incentivise and Target Shifts in Mobility Behaviour-Is It a Piece of Pie? Sensors 2015, 15, 13069-13096. [CrossRef]

40. Jin, J.; Gubbi, J.; Marusic, S.; Palaniswami, M. An Information Framework for Creating a Smart City Through Internet of Things. IEEE Internet Things J. 2014, 1, 112-121. [CrossRef]

41. Goel, S.; Kumar, R.; Kumar, A.; Malhotra, R. Smart Station Search Assistance for Electric Vehicle-A Step Toward Smart City. IEEE Consum. Electron. Mag. 2020, 9, 27-33. [CrossRef]

42. Groshev, I. Digital Transformation of Social Research and Development. Digit. Sociol. 2018, 9-17. [CrossRef]

43. Levchaev, P.A.; Khezazna, B. Transformation of Management Technologies in the Digital Economy. Digit. Transform. 2019, 39-47. [CrossRef]

44. Gobble, M.M. Digital Strategy and Digital Transformation. Res. Manag. 2018, 61, 66-71. [CrossRef] 
45. Zubritskaya, I.A. Analysis of the World Experience of Digital Transformation of Industry: Institutional Model. Digit. Transform. 2019, 21-35. [CrossRef]

46. Bruce, H. Perceptions of the Internet: What People Think When they Search the Internet for Information. Internet Res. 1999, 9, 187-199. [CrossRef]

47. Abbate, J. What and Where is the Internet? (Re)Defining Internet Histories. Internet Hist. 2017, 1, 8-14. [CrossRef]

48. Lewis, T. Who Owns the Internet? IEEE Internet Comput. 1998, 2, 82-84. [CrossRef]

49. Ruggeri, G.; Loscrí, V.; Amadeo, M.; Calafate, C.T. The Internet of Things for Smart Environments. Future Internet 2020, 12, 51. [CrossRef]

50. Zeadally, S.; Das, A.K.; Sklavos, N. Cryptographic Technologies and Protocol Standards for Internet of Things. Internet Things 2019, 100075. [CrossRef]

51. Park, J. Advances in Future Internet and the Industrial Internet of Things. Symmetry 2019, 11, 244. [CrossRef]

52. Maskeliūnas, R.; Damaševičius, R.; Segal, S. A Review of Internet of Things Technologies for Ambient Assisted Living Environments. Future Internet 2019, 11, 259. [CrossRef]

53. Abad-Segura, E.; González-Zamar, M.-D.; López-Meneses, E.; Vázquez-Cano, E. Financial Technology: Review of Trends, Approaches and Management. Mathematics 2020, 8, 951. [CrossRef]

54. Cui, X.; Huang, X.; Ma, Y.; Meng, Q. A Load Balancing Routing Mechanism Based on SDWSN in Smart City. Electronics 2019, 8, 273. [CrossRef]

55. Kendall, P. Between Big City and Authentic Village. City 2015, 19, 665-680. [CrossRef]

56. Praharaj, S.; Han, H. Cutting through the Clutter of Smart City Definitions: A Reading into the Smart City Perceptions in India. City Cult. Soc. 2019, 18, 100289. [CrossRef]

57. D'Aniello, G.; Gaeta, M.; Orciuoli, F.; Sansonetti, G.; Sorgente, F. Knowledge-Based Smart City Service System. Electronics 2020, 9, 965. [CrossRef]

58. Kulkarni, K. Smart City as System of Systems: Subject of study-Vertical Farming and Autonomous Driving in Smart city. INCOSE Int. Symp. 2019, 29, 505-517. [CrossRef]

59. Rotuna, C.; Gheorghita, A.; Zamfiroiu, A.; Smada, D.-M. Smart City Ecosystem Using Blockchain Technology. Inform. Econ. 2019, 23, 41-50. [CrossRef]

60. Ngan, N.T. Determinants Influencing to Smart City. J. Adv. Res. Dyn. Control Syst. 2020, 12, 676-681. [CrossRef]

61. Ghasemi, A.; Saberi, M. The Key Factors in Transforming Birjand City to a Smart City: Smart Mobility, Smart Government. Indones. J. Electr. Eng. Comput. Sci. 2020, 19, 317-324. [CrossRef]

62. Ashwin, M.; Vasantha, B.; Roshini, R.; Anguraj, D.K. Smart City Applications with Solutions-A Survey. Int. J. Psychosoc. Rehabil. 2019, 23, 551-557. [CrossRef]

63. Politis, S.S.; Zhang, Z.; Kouchaki, S.; Caldas, C.H. Framework for Network-Level Pavement Condition Assessment Using Remote Sensing Data Mining. J. Appl. Remote Sens. 2020, 14, 1. [CrossRef]

64. Chen, X.; Yang, Q.; Deng, B.; Wang, H. Robust Interference Waveform Design in Fuzzy Colored Noise Based on Mutual Information. J. Appl. Remote Sens. 2020, 14, 016516. [CrossRef]

65. Homainejad, A.S. With Geospatial in Path of Smart City. ISPRS-Int. Arch. Photogramm. Remote Sens. Spat. Inf. Sci. 2015, XL-7/W3, 1381-1387. [CrossRef]

66. Rafique, W.; Zhao, X.; Yu, S.; Yaqoob, I.; Imran, M.; Dou, W. An Application Development Framework for Internet-of-Things Service Orchestration. IEEE Internet Things J. 2020, 7, 4543-4556. [CrossRef]

67. Bisio, I.; Lavagetto, F.; Luzzati, G. Cooperative Application Layer Joint Video Coding in the Internet of Remote Things. IEEE Internet Things J. 2016, 3, 1418-1426. [CrossRef]

68. Kravchenko, A. The Practical Side of IoT Implementation in Smart Cities. Intellect. Arch. 2019, 8, 15-18. [CrossRef]

69. Gremban, K. IoT and "Smart” Technology. IEEE Internet Things Mag. 2019, 2, 2. [CrossRef]

70. Jiang, M.; Fu, K.-W. Chinese Social Media and Big Data: Big Data, Big Brother, Big Profit? Policy Internet 2018, 10, 372-392. [CrossRef]

71. Pilloni, V. How Data Will Transform Industrial Processes: Crowdsensing, Crowdsourcing and Big Data as Pillars of Industry 4.0. Future Internet 2018, 10, 24. [CrossRef]

72. Cremer, S.; Loebbecke, C. Artificial Intelligence Imagery Analysis Fostering Big Data Analytics. Future Internet 2019, 11, 178. [CrossRef] 
73. Pecori, R. A Virtual Learning Architecture Enhanced by Fog Computing and Big Data Streams. Future Internet 2018, 10, 4. [CrossRef]

74. Yu, H.; Yang, Z.; Sinnott, R.O. Decentralized Big Data Auditing for Smart City Environments Leveraging Blockchain Technology. IEEE Access 2019, 7, 6288-6296. [CrossRef]

75. Saranyadevi, G.; Vani, R.; Bhargavee, V.N. Waste Disposal Management System for Smart City Using LoRa. J. Adv. Res. Dyn. Control Syst. 2020, 12, 1360-1364. [CrossRef]

76. Kundu, D. Blockchain and Trust in a Smart City. Environ. Urban. ASIA 2019, 10, 31-43. [CrossRef]

77. Issaoui, Y.; Khiat, A.; Bahnasse, A.; Ouajji, H. Smart Logistics: Blockchain Trends and Applications. J. Ubiquitous Syst. Pervasive Netw. 2020, 12, 9-15. [CrossRef]

78. Abad-Segura, E.; González-Zamar, M.-D.; Infante-Moro, J.C.; Ruipérez García, G. Sustainable Management of Digital Transformation in Higher Education: Global Research Trends. Sustainability 2020, 12, 2107. [CrossRef]

79. Gong, S.; Tcydenova, E.; Jo, J.; Lee, Y.; Park, J.H. Blockchain-Based Secure Device Management Framework for an Internet of Things Network in a Smart City. Sustainability 2019, 11, 3889. [CrossRef]

80. López Meneses, E.; Leiva Olivencia, J.J.; Vázquez-Cano, E. The Impact of Personal Interactions on the Stress of School Administrators: The Validation and Application of an Assessment Tool. Intang. Cap. 2017, 13, 499. [CrossRef]

81. Kuwajima, H.; Yasuoka, H.; Nakae, T. Engineering Problems in Machine Learning Systems. Mach. Learn. 2020, 109, 1103-1126. [CrossRef]

82. Ali, M.A.; Panchal, V.K. Smart City Application Operation Using Machine Learning Algorithm. Glob. Sci-Tech 2019, 11, 215. [CrossRef]

83. Saharan, S.; Kumar, N.; Bawa, S. An Efficient Smart Parking Pricing System for Smart City Environment: A Machine-Learning Based Approach. Future Gener. Comput. Syst. 2020, 106, 622-640. [CrossRef]

84. Aujla, G.S.; Singh, M.; Bose, A.; Kumar, N.; Han, G.; Buyya, R. BlockSDN: Blockchain-as-a-Service for Software Defined Networking in Smart City Applications. IEEE Netw. 2020, 34, 83-91. [CrossRef]

85. Kretschmer, H.; Kretschmer, T.; Asundi, A.Y.; Ravichandra Rao, I.K. Dr. Eugene Garfield A humble Homage to a great information scientist. COLLNET J. Sci. Inf. Manag. 2017, 11, 5-10. [CrossRef]

86. Glänzel, W.; Abdulhayoğlu, M.A. Garfield Number: On Some Characteristics of Eugene Garfield's First and Second Order Co-Authorship Networks. Scientometrics 2017, 114, 533-544. [CrossRef]

87. Abad-Segura, E.; González-Zamar, M.-D. Global Research Trends in Financial Transactions. Mathematics 2020, 8, 614. [CrossRef]

88. González-Zamar, M.D.; Ortiz Jiménez, L.; Sánchez Ayala, A.; Abad-Segura, E. The Impact of the University Classroom on Managing the Socio-Educational Well-being: A Global Study. Int. J. Environ. Res. Public Health 2020, 17, 931. [CrossRef]

89. Álvarez-Bermejo, J.A.; Belmonte-Ureña, L.J.; Martos-Martínez, Á.; Barragán-Martín, A.B.; Simón-Márquez, M.M. Instructional Changes Adopted for an Engineering Course: Cluster Analysis on Academic Failure. Front. Psychol. 2016, 7, 1774. [CrossRef]

90. Abad-Segura, E.; Cortés-García, F.J.; Belmonte-Ureña, L.J. The Sustainable Approach to Corporate Social Responsibility: A Global Analysis and Future Trends. Sustainability 2019, 11, 5382. [CrossRef]

91. González-Zamar, M.-D.; Abad-Segura, E. La Realidad Aumentada Como Recurso Creativo En La Educación: Una Revisión Global. Rev. Creatividad Soc. 2020, 32, 164-190. [CrossRef]

92. Delgado Vázquez, Á.; Vázquez-Cano, E.; Belando Montoro, M.R.; López Meneses, E. Análisis Bibliométrico Del Impacto De La Investigación Educativa En Diversidad Funcional Y Competencia Digital: Web Of Science Y Scopus. Aula Abierta 2019, 48, 147. [CrossRef]

93. Bornmann, L.; Haunschild, R.; Hug, S.E. Visualizing the Context of Citations Referencing Papers Published by Eugene Garfield: A New Type of Keyword Co-Occurrence Analysis. Scientometrics 2017, 114, 427-437. [CrossRef] [PubMed]

94. Sánchez, A.D.; de la Cruz Del Río Rama, M.; García, J.Á. Bibliometric Analysis of Publications on Wine Tourism in the Databases Scopus and WoS. Eur. Res. Manag. Bus. Econ. 2017, 23, 8-15. [CrossRef]

95. Boldis, P.; Landova, H. Comparison of Citation Databases SCOPUS and Web of Science: Czech and Slovak Agricultural and Related Disciplines. Plant Soil Environ. 2006, 52, 481-484. [CrossRef]

96. Liberati, A.; Altman, D.G.; Tetzlaff, J.; Mulrow, C.; Gøtzsche, P.C.; Ioannidis, J.P.A.; Moher, D. The PRISMA Statement for Reporting Systematic Reviews and Meta-Analyses of Studies that Evaluate Health Care Interventions: Explanation and Elaboration. J. Clin. Epidemiol. 2009, 62, e1-e34. [CrossRef] 
97. Belmonte-Ureña, L.J.; Garrido-Cardenas, J.A.; Camacho-Ferre, F. Analysis of World Research on Grafting in Horticultural Plants. HortScience 2020, 55, 112-120. [CrossRef]

98. Abad-Segura, E.; González-Zamar, M.D. Effects of Financial Education and Financial Literacy on Creative Entrepreneurship: A Worldwide Research. Educ. Sci. 2019, 9, 238. [CrossRef]

99. Yaminfirooz, M.; Gholinia, H. Multiple H-Index: A New Scientometric Indicator. Electron. Libr. 2015, 33, 547-556. [CrossRef]

100. James, C.; Colledge, L.; Meester, W.; Azoulay, N.; Plume, A. CiteScore Metrics: Creating Journal Metrics from the Scopus Citation Index. Learn. Publ. 2019, 32, 367-374. [CrossRef]

101. Prichina, O.S. Developing and Testing the Forecasting Algorithm for the Technological Revolution Theme through the Analysis of the SCImago JR Scientific Journal Database. J. Adv. Res. Dyn. Control Syst. 2020, 12, 712-724. [CrossRef]

102. Brown, T.; Gutman, S.A. Impact Factor, Eigenfactor, Article Influence, Scopus SNIP, and SCImage Journal Rank of Occupational Therapy Journals. Scand. J. Occup. Ther. 2018, 26, 475-483. [CrossRef] [PubMed]

103. Uddin, S.; Hossain, L.; Abbasi, A.; Rasmussen, K. Trend and Efficiency Analysis of Co-Authorship Network. Scientometrics 2011, 90, 687-699. [CrossRef]

104. Ponomariov, B.; Boardman, C. What is Co-Authorship? Scientometrics 2016, 109, 1939-1963. [CrossRef]

105. Fellnhofer, K. Visualised Bibliometric Mapping on Smart Specialisation: A Co-Citation Analysis. Int. J. Knowl.-Based Dev. 2018, 9, 76. [CrossRef]

106. Zhou, S.; Tao, Z.; Zhu, Y.; Tao, L. Mapping Theme Trends and Recognizing Hot Spots in Postmenopausal Osteoporosis Research: A Bibliometric Analysis. Peer] 2019, 7, e8145. [CrossRef]

107. Whelan, F.J.; Rusilowicz, M.; McInerney, J.O. The Co-Occurrence and Co-Exclusion of Evolving Objects in Prokaryotes. Access Microbiol. 2019, 1. [CrossRef]

108. Zhou, Q.; Leydesdorff, L. The Normalization of Occurrence and Co-Occurrence Matrices in Bibliometrics Using Cosinesimilarities and Ochiaicoefficients. J. Assoc. Inf. Sci. Technol. 2015, 67, 2805-2814. [CrossRef]

109. Arita, H.T. Multisite and Multispecies Measures of Overlap, Co-Occurrence, and Co-Diversity. Ecography 2017, 40, 709-718. [CrossRef]

110. Van Eck, N.J.; Waltman, L. Citation-Based Clustering of Publications Using CitNetExplorer and VOSviewer. Scientometrics 2017, 111, 1053-1070. [CrossRef]

111. Waltman, L.; van Eck, N.J. Source Normalized Indicators of Citation Impact: An Overview of Different Approaches and an Empirical Comparison. Scientometrics 2012, 96, 699-716. [CrossRef]

112. Delibasoglu, I.; Cetin, M. Hyperspectral Band Selection Using Structural Information via Hierarchical Clustering. J. Appl. Remote Sens. 2019, 13, 014526. [CrossRef]

113. Badshah, A.; Ghani, A.; Ahsan Qureshi, M.; Shamshirband, S. Smart Security Framework for Educational Institutions using Internet of Things (IoT). Comput. Mater. Contin. 2019, 61, 81-101. [CrossRef]

114. Ali Haidery, S.; Ullah, H.; Khan, N.U.; Fatima, K.; Rizvi, S.S.; Kwon, S.J. Role of Big Data in the Development of Smart City by Analyzing the Density of Residents in Shanghai. Electronics 2020, 9, 837. [CrossRef]

115. Roy, S.K.; De, D. Genetic Algorithm based Internet of Precision Agricultural Things (IopaT) for Agriculture 4.0. Internet Things 2020, 100201. [CrossRef]

116. Pagliaro, M.; Meneguzzo, F. Digital Management of Solar Energy En Route to Energy Self-Sufficiency. Glob. Chall. 2019, 3, 1800105. [CrossRef]

117. Starodubtsev, G.; Starodubstev, Y. Quality of Digital Information Resources in Condition of Global Info-Telecommunication System Multifaceted Management. IOP Conf. Ser. Mater. Sci. Eng. 2019, 497, 012135. [CrossRef]

118. Vera-Baceta, M.-A.; Thelwall, M.; Kousha, K. Web of Science and Scopus Language Coverage. Scientometrics 2019, 121, 1803-1813. [CrossRef]

119. Tran-Dang, H.; Krommenacker, N.; Charpentier, P.; Kim, D.-S. Towards the Internet of Things for Physical Internet: Perspectives and Challenges. IEEE Internet Things J. 2020, 7, 4711-4736. [CrossRef]

120. Lytras, M.; Visvizi, A. Who Uses Smart City Services and What to Make of It: Toward Interdisciplinary Smart Cities Research. Sustainability 2018, 10, 1998. [CrossRef]

121. Hajikhani, A. Impact of Entrepreneurial Ecosystem Discussions in Smart Cities: Comprehensive Assessment of Social Media Data. Smart Cities 2020, 3, 112-137. [CrossRef]

122. Zanella, A.; Bui, N.; Castellani, A.; Vangelista, L.; Zorzi, M. Internet of Things for Smart Cities. IEEE Internet Things J. 2014, 1, 22-32. [CrossRef] 
123. Capra, M.; Peloso, R.; Masera, G.; Roch, M.R.; Martina, M. Edge Computing: A Survey on the Hardware Requirements in the Internet of Things World. Future Internet 2019, 11, 100. [CrossRef]

124. Aurigi, A.; Odendaal, N. From "Smart in the Box" to "Smart in the City": Rethinking the Socially Sustainable Smart City in Context. J. Urban Technol. 2020, 1-16. [CrossRef]

125. Konovalova, T.A. The Perception of-A Smart City in Terms of Cognitive Interpretation on the Example of the Notion and Image of-A Smart City among Students (Future Architects). Int. J. Psychosoc. Rehabil. 2020, 24, 4954-4972. [CrossRef]

126. Roopa, M.; Sujitran, M.; Saivikas. Efficient Waste Management System for Smart City using LoRa. Int. J. Psychosoc. Rehabil. 2020, 24, 3465-3476. [CrossRef]

127. Ficco, M. Internet-of-Things and Fog-Computing as Enablers of New Security and Privacy Threats. Internet Things 2019, 8, 100113. [CrossRef]

128. Guan, Z.; Jia, Y.; He, M. A Bidirectional Polling MAC Mechanism for IoT. Electronics 2019, 8, 715. [CrossRef]

129. Xiao, J.; Zhang, B.; Luo, F. Distribution Network Security Situation Awareness Method Based on Security Distance. IEEE Access 2019, 7, 37855-37864. [CrossRef]

130. Adat Vasudevan, V.; Tselios, C.; Politis, I. On Security Against Pollution Attacks in Network Coding Enabled 5G Networks. IEEE Access 2020, 8, 38416-38437. [CrossRef]

131. Arora, K.; Singh, J.; Randhawa, Y.S. A Survey on Channel Coding Techniques for 5G Wireless Networks. Telecommun. Syst. 2019, 73, 637-663. [CrossRef]

132. Lian, J.; Gao, Y.; Wang, H. Underwater Optical Wireless Sensor Networks Using Resource Allocation. Telecommun. Syst. 2019, 71, 529-539. [CrossRef]

133. Kölsch, J.; Heinz, C.; Ratzke, A.; Grimm, C. Simulation-Based Performance Validation of Homomorphic Encryption Algorithms in the Internet of Things. Future Internet 2019, 11, 218. [CrossRef]

134. Rejeb, A.; Keogh, J.G.; Treiblmaier, H. Leveraging the Internet of Things and Blockchain Technology in Supply Chain Management. Future Internet 2019, 11, 161. [CrossRef]

135. Islam, M.; Reza, S. The Rise of Big Data and Cloud Computing. Internet Things Cloud Comput. 2019, 7, 45. [CrossRef]

136. Paranjape, K.; Guimaraes, T. User Support as Moderator for Cloud Computing User Satisfaction. Int. J. Cloud Comput. 2019, 8, 150. [CrossRef]

137. Fíla, O.; Sellner, K.; Vysloužilová, D.; Klimecka-Tatar, D. Safety and Automatization of Machining Line. Syst. Saf. Hum.-Tech. Facil.—Environ. 2020, 2, 268-274. [CrossRef]

138. Sharaf Dabbagh, Y.; Saad, W. Authentication of Wireless Devices in the Internet of Things: Learning and Environmental Effects. IEEE Internet Things J. 2019, 6, 6692-6705. [CrossRef]

139. Gardner, N.; Hespanhol, L. SMLXL: Scaling the Smart City, from Metropolis to Individual. City Cult. Soc. 2018, 12, 54-61. [CrossRef]

140. Shushrutha, D.; Reddy, G.K. A Study on IoT Based Smart Garbage and Waste in Smart City. Int. J. Comput. Sci. Eng. 2019, 7, 629-631. [CrossRef]

141. Mahase, E. Covid-19: Trump Threatens to Stop Funding Who Amid "China-Centric" Claims. BMJ 2020, 369, m1438. [CrossRef]

142. Fu, W.; Narayan, D. Optimization Algorithm for Embedded Linux Remote Video Monitoring System Oriented to the Internet of Things (IoT). Discret. Contin. Dyn. Syst.-S 2019, 12, 1341-1354. [CrossRef]

143. Mahbub, M. A Smart Farming Concept Based on Smart Embedded Electronics, Internet of Things and Wireless Sensor Network. Internet Things 2020, 9, 100161. [CrossRef]

144. Kumawat, D.V.; Umamaheswari, B. Internet of Things IoT Based Smart Environment Integrating Various Business Applications and Recent Research Directions. Int. J. Trend Sci. Res. Dev. 2019, 3, 422-425. [CrossRef]

145. Dryjanski, M.; Buczkowski, M.; Ould-Cheikh-Mouhamedou, Y.; Kliks, A. Adoption of Smart Cities with a Practical Smart Building Implementation. IEEE Internet Things Mag. 2020, 3, 58-63. [CrossRef]

146. Badii, C.; Bellini, P.; Difino, A.; Nesi, P. Smart City IoT Platform Respecting GDPR Privacy and Security Aspects. IEEE Access 2020, 8, 23601-23623. [CrossRef]

147. Fallis, E.; Spachos, P.; Gregori, S. A power-Efficient Audio Acquisition System for Smart City Applications. Internet Things 2020, 9, 100155. [CrossRef]

148. Alam, M.K.; Ahmed, M.; Naz, F. Internet of Things Technologies for Smart Towns: A Remote System for Making Town Smart. Int. J. Trend Sci. Res. Dev. 2018, 2, 1366-1370. [CrossRef] 
149. Austin, M.; Delgoshaei, P.; Coelho, M.; Heidarinejad, M. Architecting Smart City Digital Twins: Combined Semantic Model and Machine Learning Approach. J. Manag. Eng. 2020, 36, 04020026. [CrossRef]

150. Czupich, M. The Role of ICT in the Smart City Concept. Olszt. Econ. J. 2019, 14, 63-74. [CrossRef]

151. Mukherjee, A.; De, D.; Ghosh, S.K. FogIoHT: A Weighted Majority Game Theory Based Energy-Efficient Delay-Sensitive Fog Network for Internet of Health Things. Internet Things 2020, 11, 100181. [CrossRef]

152. Lynggaard, P.; Skouby, K. Complex IoT Systems as Enablers for Smart Homes in a Smart City Vision. Sensors 2016, 16, 1840. [CrossRef] [PubMed]

153. Kohli, M.; Tiwari, R. IoT - An Exquisitely Adequate Technology to Reinforce the "City of Future-Smart City". IJARCCE 2018, 7, 11-14. [CrossRef]

154. European Innovation Partnership on Smart Cities and Communities (EIP-SCC) European Comission. Available online: https://eu-smartcities.eu/ (accessed on 15 July 2020).

155. Rocha, C.; Fernandes Narcizo, C.; Gianotti, E. Internet of Management Artifacts: Internet of Things Architecture for Business Model Renewal. Int. J. Innov. Technol. Manag. 2019, 16, 1950062. [CrossRef]

156. Alliance for Internet of Things Innovation. Available online: https://aioti.eu/ (accessed on 21 July 2020).

157. Smart Cities World. Available online: https://www.smartcitiesworld.net/home (accessed on 21 July 2020).

158. Smart City.Press. Available online: https://www.smartcity.press/ (accessed on 20 July 2020).

159. IoT World Today. Available online: https://www.iotworldtoday.com/ (accessed on 21 July 2020).

(C) 2020 by the authors. Licensee MDPI, Basel, Switzerland. This article is an open access article distributed under the terms and conditions of the Creative Commons Attribution (CC BY) license (http://creativecommons.org/licenses/by/4.0/). 